\title{
Establishing integrated agriculture-nutrition programmes to diversify household food and diets in rural India
}

\author{
A. V. Vijaya Bhaskar ${ }^{1}$ - D. J. Nithya ${ }^{2} \cdot$ S. Raju $^{2} \cdot$ R. V. Bhavani ${ }^{2}$
}

Received: 15 July 2016 / Accepted: 22 August 2017 /Published online: 30 September 2017

(C) The Author(s) 2017. This article is an open access publication

\begin{abstract}
Agriculture is the predominant livelihood for $70 \%$ of the population living in rural India, and food expenses occupy a major proportion of their household budget. Rural household diets suggest that agricultural growth has contributed to increasing calorie intake with very minimal effect on the intake of protein and micronutrients. This in turn causes weak positive impact of agriculture on household dietary diversity and nutrient adequacy. Given the prevalence of high levels of under-nutrition and a large population dependent on agriculture, recent thinking globally on leveraging agriculture for nutrition security has encouraged the agricultural sector to realign its focus not only to increase food production, but also to address under-nutrition. Against this background, an exploratory study was conducted in resource poor villages of Wardha and Koraput districts in the states of Maharashtra and Odisha in India, to investigate how location-specific Farming System for Nutrition (FSN) interventions can potentially improve the diversity of household diets and nutrition outcomes. A detailed baseline study was undertaken to identify the existing disconnect between agriculturenutrition linkages. In the study locations, the proportion of all forms of under-nutrition, vitamin A deficiency and iron-deficiency anaemia among children $<5$-years of age appeared unacceptably high. A high prevalence rate of chronic energy deficient (CED) women and anaemic pregnant women was also observed. A higher risk of under-nutrition and
\end{abstract}

R. V. Bhavani

bhavani@mssrf.res.in

1 Department of Ecological Plant Protection, University of Kassel, Nordbahnhofstr.1a, 37213 Witzenhausen, Germany

2 Research Programme on Leveraging Agriculture for Nutrition in South Asia (LANSA), M.S. Swaminathan Research Foundation (MSSRF), Chennai, Tamilnadu 600 113, India micronutrient deficiency among household members was associated with substandard living conditions of the surveyed households. Cropping systems in Wardha were primarily dominated by rain-fed commercial cash crops while rain-fed subsistence farming predominated in Koraput. Households in both study locations were found to have cereal-dominated diets with average daily consumption of pulses, fruits and vegetables, and milk and milk products well below the recommended daily intake level, indicating low dietary diversity. In both Wardha and Koraput, CED in adults ( $>18$ years) significantly increased as the dietary diversity score (DDS) decreased from high to low. In Koraput, the prevalence rate of anaemia in adolescent girls and women significantly increased, as the DDS decreased. We conclude that food and diets lacking diversity and without nutrition-sensitive farming systems (either commercial- or subsistence-based) may not be appropriate to improve household nutrition and health status. Our findings provide a basis for structuring integrated agriculture-nutrition programmes or a FSN approach to diversifying household food and diets, for improving nutrition and health in India.

Keywords Farming system $\cdot$ Nutrition security $\cdot$ Koraput . Wardha $\cdot$ Dietary diversity $\cdot$ Household food security

\section{Introduction}

Food grain production in India crossed 260 million tonnes during 2012-14 (GoI 2015a). However, in the same period, about 190.7 million persons (15.2\% of the total population) living in rural areas remained chronically undernourished (FAO, IFAD and WFP 2014). The National Family Health Survey (NFHS-4) reported that among rural children under age five, $41 \%, 21 \%$ and $38 \%$ are stunted, wasted and 
underweight respectively (GoI 2017). The latest Global Nutrition Report highlighted that $48 \%$ of rural Indian women in the reproductive age group are anaemic (IFPRI 2016). This figure stood even higher at 54\% in NFHS-4 (GoI 2017). Despite recent significant gains in economic progress and agricultural productivity, under-nutrition remains a challenge in India. The terminal year of the UN Millennium Development Goals (December 2015) saw India lagging in achieving the target of reducing under-nutrition, while achieving the target for reducing poverty ( $\mathrm{GoI} 2015 \mathrm{~b}$ ).

Three widely reported indicators for food and nutrition insecurity at the household level are the unavailability of food, inaccessibility of food produced, and the available or accessible food does not ensure a balanced diet (Das et al. 2014; Masset et al. 2011). Agriculture remains an important focus for pro-poor and pro-rural nutritional interventions in India. Almost $69 \%$ of the population live in rural areas according to Census 2011 (Chandramouli 2011) and more than half the workforce are engaged in agriculture and allied activities. This makes leveraging agriculture to address under-nutrition a key area of focus. Increased food production certainly improves food availability, but by itself does little to ensure that poor and vulnerable people have access to the food produced; neither does it provide information related to the quality and enrichment of the food that is produced (World Bank 2007). There is also evidence that increased income does not necessarily address a shift in diet preferences (Global Panel 2015; World Bank 2007). The problem of under-nutrition therefore has to be dealt with by addressing compounding factors that include nutrition-sensitive agriculture, increasing incomes, improving food accessibility, shifting dietary patterns, nutrition education and health awareness.

Evidence is found in the literature of the different pathways linking agriculture and nutrition (World Bank 2007; FAO 2013; Kadiyala et al. 2014; Kadiyala et al. 2016; Gillespie and van den Bold 2017). Taking into account the spatial influence of farming practices, cultural settings, resource availability at a household level, and soil and agro-ecological environment, what may be considered a fitting strategy at one place, while providing the framework, is unlikely to be directly applicable in a different setting. Led by the M.S. Swaminathan Research Foundation (MSSRF), the research programme on Leveraging Agriculture for Nutrition in South Asia (LANSA) seeks evidence on 'How agricultural interventions can be pro-nutrition?' Farming System for Nutrition (FSN), as defined by M.S. Swaminathan, envisages 'the introduction of location-specific agricultural remedies for nutritional maladies by mainstreaming nutritional criteria in the selection of farm-household system components involving crops, animals and, wherever feasible, fish' (Das et al. 2014; Nagarajan et al. 2014). As suggested by Varian (1992), FSN includes a set of 'agricultural curatives' (the combination of available farm resources including improved seeds, soil technology, bio-fortification, setting up small-scale fisheries, poultry development, animal husbandry, homestead and community nutrition gardening) as inputs to raise income and improve nutrition. The underlying hypothesis is that nutritional outcomes and dietary diversification in a rural population improves through agricultural production for consumption (direct) or by production for sale (indirect) (World Bank 2007). In general, a diet is the composition of the food basket consumed by the household. An improvement in diet can be the outcome of diversification into non-staple foods and/or enrichment with items from among regularly consumed staple foods (Masset et al. 2011).

A systematic exploratory study was initiated in selected resource-poor villages of Wardha district in the state of Maharashtra and Koraput district in the state of Odisha to investigate how location-specific FSN interventions can improve household diet and nutrition outcomes. To establish integrated agriculture-nutrition programmes, it is important to understand the underlying causes that limit food and nutrition security in a household. Baseline information provides a reference point for monitoring and evaluation of the progress and effectiveness of the integrated agriculture-nutrition programmes. It provides the starting point for effective structuring of activities related to FSN interventions. In addition, the baseline study gathers the information to be used in subsequent assessments of how efficiently the activity is being implemented and the ultimate results of the activity, and forms a basis for ensuring accountability to the rural households who are at risk of under-nutrition.

The present study is one of the first to systematically unfold agriculture, nutrition and health complexities in districts with a high burden of under-nutrition in India. As seen in other developing countries (Cole et al. 2016; Jolley 2014; Donaldson 2015), the agriculture, nutrition and health sectors in India largely operate in separate 'silos', administratively governed by different Ministries and professionally by separate scientific and expert workforces (Nagarajan et al. 2014). This situation has resulted in an extended gap between agriculture and health. The role of food, access to food and balanced diet that is so crucial for human well-being has emerged as a major concern (Nagarajan et al. 2014). Realistic agricultural policy support has done little to protect farmers against risks including those from climate change and pressure of population on land, or to promote rural prosperity. Agricultural policy in India has focused primarily on strengthening the production of staple food crops, especially rice and wheat, through price incentives and the promotion of farm technologies (Das et al. 2014). This approach, while addressing food security, has led to the neglect of several naturallyfortified food crops and crop diversification, contributing to soil impoverishment and limiting dietary diversity.

Thus in rural India, farmers and landless agricultural and non-agricultural labourers are disregarded, both economically 
and agriculturally, and from nutrition and health perspectives. The selected districts for this study, Wardha and Koraput, are classic examples of such marginalisation. Agriculture is the primary occupation of the population in both of the study locations, implying that better agriculture could be a potential solution to combat nutrition and health inadequacies. Recent studies have documented that changes in climate and continuous repetitive cropping patterns over many years have resulted in stagnant or reduced yields in these locations and across many other Indian rural settings (Nayak 2016; Talule 2015; Udmale et al. 2015; Wani et al. 2016). Livelihood risk and vulnerability has increased due to deteriorating cost/benefit ratios. Agrarian crises and farmer suicide has been extensively documented in Wardha (Sontakke 2015; Kulkarni et al. 2016) while Koraput is an agro-biodiversity hotspot, threatened by erosion of natural resources and food insecurity (Anil Kumar et al. 2015).

Holistic and integrated situational analyses will help to identify the root causes of agricultural and nutrition deficiencies among rural households; and also bring together stakeholders to work together with farmers to seek solutions for households and for policy makers. Pro-nutrition agriculture allows for the testing of some promising crops such as biofortified zinc- and iron-rich wheat (Singh and Velu 2017; Rosado et al. 2009), orange-fleshed sweet potato (Waized et al. 2015; Borrill et al. 2014), and quality-protein maize (Akalu et al. 2010; Gunaratna et al. 2010), along with soil improving cropping strategies, with farmers' involvement in farm environments. Studies with these key crops reportedly produced beneficial results for improved nutrition and provided higher price margins. Like elsewhere, adopting key crops within a FSN approach has the highest expectation in promoting nutrition and food security in the selected study villages. Overall, the strategic framework developed as a part of this investigation will deliver valuable insights into the planning and execution of multi-sectoral interventions to address multidimensional problems with links between agriculture, nutrition and health.

\section{Methods}

\subsection{Description of the study locations}

The FSN study locations were purposively selected on the basis of agro-climatic and socio-economic status, landholding pattern, farming practices and food consumption pattern. More information on the study locations has been reported by Das et al. (2014) and Nagarajan et al. (2014). Despite soil and agro-ecological differences between the study areas, both are characterized by rain-fed farming and by high levels of under-nutrition. The Government of India's Census data for 2011 provided preliminary socio-demographic information about the study intervention areas. Based on this, eight villages comprising 822 households with a population of 3287 in Wardha and eleven villages with 921 households and a population of 3958 in Koraput were identified for the baseline study and subsequent planning of integrated agriculturenutrition programmes.

\subsection{Data collection instruments}

Experienced field investigators (including enumerators) and survey teams (including qualified phlebotomists) were selected, re-trained and standardized in the survey methodology by former and current scientists of the National Institute of Nutrition (NIN), Hyderabad, India, before initiation of the survey. The training took place over two weeks and covered all the techniques of investigation that were used. To collect reliable information, the field investigators and survey teams committed substantial time to build rapport with the rural householders in both study areas, to ensure good working relationships. Participating households were made fully aware of the need for baseline information for advancing FSN interventions. The approach allowed the conduct of multiple surveys from June 2013 to September 2014 to collect the information described in the next sections.

\subsubsection{Socio-demographic characteristics}

A socio-demographic questionnaire elicited household demographic and socio-economic information. The questionnaire included questions on caste, age, gender, family size, education and occupation of household heads, size of agricultural land owned and preferred Kharif (June to October) and Rabi (November to March) agricultural season crops, livestock holdings, traditional homestead gardening and the types and mix of horticultural crops. Other questions included type of dwelling, fuel used for cooking, type of toilet, and the sources of drinking water. Additional questions included the types of food bought in the household, their source, monthly expenditure on food, and who makes decisions on the amount of money spent on food, which in turn impacts on household food and diets.

\subsubsection{Anthropometric measurements}

The height and weight of all the household members in both study areas were measured using standard equipment (Seco weight balance, stadiometer and infantometer). The percent distribution of preschool children according to underweight (weight-for-age $Z$-score (WAZ) at least two standard deviations (SD) below the median), stunted (height-for-age $Z$-score (HAZ) at least 2SD below the median) and wasted (weight-for-height (WHZ) Z-score at least 2SD below the median) was determined based on the World Health Organization 
child growth standards (WHO 2006). WHO Anthro (version $3.2 .2,2011$ ) and Anthroplus (2007) software were used to calculate the $Z$-scores. School-age children and adolescents were categorized according to age/sex specific Body Mass Index (BMI) recommended by the WHO (BMI Z-score (BMIZ) at least 2SD below the median) classification; adult nutritional status was categorized by BMI according to WHO cut off levels for Asians (Chronic Energy Deficiency (CED) $<18.5 \mathrm{BMI}$ ).

\subsubsection{Biochemical analysis}

At both the locations, finger prick blood samples were obtained for biochemical analysis from households having children in the age group of $1-5$ years, adolescent girls in the age group of 12-17 years and women in the age group of 18-45 years. The blood sample of children was tested for serum vitamin A and haemoglobin $(\mathrm{Hb})$. For adolescent girls and women, the analysis was limited to haemoglobin. The blood samples were collected using a filter paper technique to estimate the haemoglobin levels by the cyanmethaemoglobin method (Drabkin's method) and blood vitamin A levels by dried blood spot technique using High Performance Liquid Chromatography (HPLC). The collected samples were analysed at the NIN. The WHO cut off levels were used to diagnose the extent and degree of iron-deficiency anaemia (anaemic: $\mathrm{Hb}<11 \mathrm{~g} / \mathrm{dl}$ for children in the age $1-5$ years and pregnant women; $\mathrm{Hb}<12 \mathrm{~g} / \mathrm{dl}$ for girls in the age 12 to 45 years and lactating and non-pregnant non-lactating women) and vitamin A deficiency (VAD) (blood vitamin A $<20 \mu \mathrm{g} / \mathrm{dl})$.

\subsubsection{Food consumption pattern}

A one-day 24-h diet recall method of an intra-household diet survey was administered on a selected sub-sample of 300 households in Wardha and 300 in Koraput. A 24-h diet recall method was performed continuously over a period of time to capture food intake patterns on all days including Sunday, given the general habit of consuming animal-sourced food on holidays. The main criterion for sub-sampling included households with children in the age group of $1-5$ years. This was to ensure we obtained information on food intake and biochemical analysis for the same set of households. In case households did not have children in this category, households with adolescent girls in the age group of 12-17 years whose blood haemoglobin levels had been analysed were included, to obtain a total of 300 households following purposive sampling. The mean intakes of food were compared with the suggested balanced diet provided in 'Recommended Dietary Intakes for Indians' (RDI) by the Indian Council of Medical Research (ICMR 2012). In addition, it was presumed that a household should consume by reference at least $70 \%$ of the
RDI. Using this reference, the frequency distribution (\%) of households according to a level of food intake of less than $70 \%$ of RDI was estimated. However, out of the thirteen food groups studied (listed in the next section), nuts and oil seeds, condiments and spices, fish and other sea foods, and meat and poultry were not used for this calculation as there was no ICMR-RDI reference.

\subsubsection{Dietary diversity}

Dietary diversity is a qualitative measure of food consumption reflecting household access to a variety of foods, and is also a proxy for nutrient adequacy of the diet of individuals (Coates et al. 2007). The dietary diversity score (DDS) was estimated using 24-h diet recall data for each person based on thirteen food groups as recommended by ICMR (2012). The groups included (1) cereals and millets, (2) pulses and legumes, (3) green leafy vegetables, (4) roots and tubers, (5) other vegetables, (6) nuts and oil seeds, (7) condiments and spices, (8) fruits, (9) fish and other sea foods, (10) meat and poultry, (11) milk and milk products, (12) fat and edible oils, and (13) sugars and jaggery. The variable DDS was calculated by summing the number of food groups consumed by the household with the scores ranging from 1 to 13 as given by FAO (2011). This was done after creating food group variables for those food groups that needed to be aggregated. The maximum and ideal score would be a DDS of 13 since this would mean that the individual had consumed from each of the 13 food groups at least once. The calculated DDS were further categorized into tertiles: low (1 to 7), medium (8), and high (9 to 13) dietary diversity based on the score distribution within the population.

\subsection{Statistical analysis}

In addition to descriptive statistics, Pearson's chi-square test was conducted to determine the association of some household socio-demographic variables with nutritional status of individuals, and the association of nutrition status with DDS. Statistical Package for Social Sciences (SPSS) software version 20.0 was used to perform descriptive statistics and the chi-square test. Significance level was fixed at 0.05. Following a chi-square test, student's t-test (two-group mean comparison test using Stata software, version 12.0) was performed to help further understand the relationship of statistically significant variables. The majority of the population in a category was considered as a base reference while making the comparison. In our study with a large sample size, the data distribution appeared highly skewed, indicating extremely large variation within the group. A multivariate analysis that attempted to control socio-demographic variables yielded non-significant results. Hence a bi-variate analysis was 
performed to better understand the relationships, as suggested by O’ Donnell et al. (2008).

\section{Results}

\subsection{Socio-demographic status and farming practices of the study population}

Indigenous tribal communities, classified as Scheduled Tribes under the Constitution of India, constituted the majority $(46.3 \%)$ of the human population in the selected villages we studied. As high as $53.8 \%$ of total rural households in the study areas lived in kutcha houses and the remaining $46.2 \%$ in semi-pucca houses. ${ }^{1}$ A majority of households $(59.7 \%)$ were nuclear (with 1-4 members) and 37\% had 5-7 members (extended nuclear families). On the basis of age classification, $40.8 \%$ of the rural population were in the working age group of 18-44 years, $25.4 \%$ were above 45 years and a small percentage of between 10 and $12 \%$ were in the age groups of $12-$ $17,6-11$ and $0-5$ years, respectively. Table 1 gives the sociodemographic characteristics of the study villages.

In terms of sanitation conditions, nearly $52 \%$ of households in Wardha had access to piped water for drinking whilst $66 \%$ of households in Koraput sourced it from a tube-well. Almost all $(98 \%)$ of the households used wood as fuel for cooking. Most households (89\%) practiced open defecation. However, in Wardha $22 \%$ of households had a sanitary latrine facility, in contrast to only $1.2 \%$ in Koraput.

In Koraput, most (66\%) household heads had no formal education; the corresponding figure was $22 \%$ in Wardha. About $56.8 \%$ of household heads were cultivators, $26 \%$ agricultural wage labours and $17.5 \%$ other casual labour/daily wage earners. Based on the total landholding size, the Agriculture Census of India ${ }^{2}$ categorises farm-households with an agricultural land area of less than 1 ha as marginal farmers; those cultivating a land area of more than 1 ha but less than 2 ha as small farmers; and those cultivating more than 2 ha but less than 4 ha and more than 4 ha of land area as semi-medium and medium farmers respectively. Households not holding agricultural land are classified as landless. On the basis of this classification, in Koraput $80.7 \%$ of the farmhouseholds were marginal farmers, $16.6 \%$ were landless and a very small proportion, $2.2 \%$ and $0.5 \%$ of farm-households respectively were small and semi-medium farmers. In contrast, in Wardha, about 37.2\% households reported being landless and $10.1 \%$ were marginal farmers; small and semi-

\footnotetext{
${ }^{1}$ A kutcha house is a house with a wall or roof made from mud, thatch, straw, dry leaves or reeds. A semi-pucca house is a house with either the wall or roof made of pucca materials such as burnt bricks, cement, concrete or tiles. (Census of India definition, Retrieved: http://shodhganga.inflibnet.ac.in/ bitstream/10603/63163/21/21_appendix\%204.pdf).

${ }^{2}$ Retrived: http://agcensus.nic.in/document/agcensus2010/agcen2010rep.htm
}

medium farmers accounted for $25.9 \%$ and $18.9 \%$ of farm households respectively. In Koraput, $71 \%$ of the households reported to have farm animals (single or combination of small ruminants, milch animals, draught animals and poultry) in contrast to $55 \%$ in Wardha.

Considerable variation was observed between Wardha and Koraput, in the number of households practicing traditional homestead gardening and the size of allocated backyard land. In Koraput, $48 \%$ of the households practiced traditional homestead gardening while only $15 \%$ did in Wardha. Among traditional gardening households in Wardha, the reported available backyard land area per household on an average was $2.43 \pm 6.07$ (mean $\pm \mathrm{SD}) \mathrm{m}^{2}$. Irrespective of seasons, the types of horticultural crops cultivated included beans, brinjal, papaya, guava, lemon, bitter gourd, custard apple and green chillies. Very limited cultivation of spinach, tomato, radish, carrot, onion and pumpkin was reported. In general, about $50 \%$ of traditional gardening households grew only one type of horticulture crop, $30.7 \%$ grew two types and only $11.3 \%$ and $10 \%$ reported three and four or more types and a mix of horticultural crops. In Koraput, traditional home gardening households reported an average $6.88 \pm 3.24$ (mean $\pm \mathrm{SD}$ ) $\mathrm{m}^{2}$ of available backyard land per household. Most households grew broad bean, tomato, brinjal, onion, green chillies, amaranths, cauliflower, radish, spine gourd, cabbage, field bean, garlic and papaya. Very limited bottle gourd, mustard, spinach, and ginger was reported. In general, about $34.5 \%$ of traditional gardening households grew two types and a mix of horticultural crops, $25.6 \%$ one type and only $20.9 \%$ and $19 \%$ reported three and four or more types and mix of horticultural crops. Nevertheless, despite having backyard space, $67 \%$ of the total population did not practice home gardening.

In the majority of households, the husband and wife (74\%) jointly made the decision on how much money was spent on food and the types of food to be purchased. In Koraput, $31 \%$ of households spent less than 1000 Indian rupees (Rs.) ( US $\$ 15.44$ ) per month on food items. About $55 \%$ of households spent Rs. 1000 to less than Rs. 2000, and only a small percentage of households (14\%) spent Rs. 2000 or more on food items. In contrast, $41.1 \%$ of households in Wardha spent Rs. 2000 to less than Rs. 3000 on food items, 38.3\% spent Rs. 1000 to less than Rs. 2000 and a very small percentage of $4.3 \%$ spent less than Rs. 1000.

For crop types in Wardha, from the total of 822 households, $62.8 \%$ of households cultivated Kharif season crops (rainfed). The percentage was derived using total households by total landholders. Among Kharif growers, 34.5\% of farmhouseholds strip-cropped Bt-cotton with pigeon pea (Fig. 1). Typically, Bt-cotton + pigeon pea occupied most of the land area, $26.5 \%$ of households additionally used some proportion of land area to cultivate soybean and $22 \%$ sorghum (mainly for fodder). The remaining households (17\%) reported sole cropping mostly soybean, desi cotton, pigeon pea or sorghum. 
Table 1 Socio-demographic characteristics of the study villages in Wardha and Koraput in India

\begin{tabular}{|c|c|c|c|}
\hline Demographic and socio-economic characteristics & Wardha $N^{*}(\%)$ & Koraput $N^{*}(\%)$ & Total for both districts $N^{*}(\%)$ \\
\hline \multicolumn{4}{|l|}{ Population } \\
\hline Scheduled tribes & $401(48.8)$ & $406(44.1)$ & $807(46.3)$ \\
\hline Scheduled caste & $107(13.0)$ & $120(13.0)$ & $227(13.0)$ \\
\hline Other castes & $314(38.2)$ & $395(42.9)$ & 709 (40.6) \\
\hline \multicolumn{4}{|l|}{ Dwelling types } \\
\hline Kutcha & $414(50.4)$ & $524(56.9)$ & $938(53.8)$ \\
\hline Semi-pucca & $408(49.6)$ & $397(43.2)$ & $805(46.2)$ \\
\hline \multicolumn{4}{|l|}{ Gender } \\
\hline Male & $1722(52.4)$ & $1874(47.3)$ & $3596(49.6)$ \\
\hline Female & $1565(47.6)$ & $2084(52.7)$ & $3649(50.4)$ \\
\hline \multicolumn{4}{|l|}{ Family size } \\
\hline 1 to 4 & $540(65.7)$ & $500(54.3)$ & $1040(59.7)$ \\
\hline 5 to 7 & $265(32.2)$ & $380(41.3)$ & $645(37.0)$ \\
\hline 8 and above & $17(2.1)$ & $41(4.5)$ & $58(3.3)$ \\
\hline \multicolumn{4}{|l|}{ Age group } \\
\hline $0-5$ years & $282(8.6)$ & $472(11.9)$ & $754(10.4)$ \\
\hline $6-11$ years & $255(7.8)$ & $588(14.9)$ & $843(11.6)$ \\
\hline $12-17$ years & $345(10.4)$ & $501(12.7)$ & $846(11.7)$ \\
\hline $18-44$ years & $1435(43.7)$ & $1524(38.5)$ & $2959(40.8)$ \\
\hline$>=45$ years & $970(29.5)$ & $873(22.1)$ & $1843(25.4)$ \\
\hline \multicolumn{4}{|l|}{ Sources of drinking water } \\
\hline Dug well & $219(26.6)$ & $193(21.0)$ & $412(23.6)$ \\
\hline Piped water & $428(52.1)$ & $117(12.7)$ & $545(31.3)$ \\
\hline Tube well & $175(21.3)$ & $611(66.3)$ & $786(45.1)$ \\
\hline \multicolumn{4}{|l|}{ Cooking fuel } \\
\hline Fire wood & $794(96.6)$ & 917 (99.6) & $1711(98.2)$ \\
\hline Gas & $28(3.4)$ & $4(0.4)$ & $32(1.8)$ \\
\hline \multicolumn{4}{|l|}{ Toilet type } \\
\hline Toilets & $177(21.5)$ & $11(1.2)$ & $188(11.3)$ \\
\hline Open defecation & $648(78.5)$ & $909(98.8)$ & $1557(88.7)$ \\
\hline \multicolumn{4}{|l|}{ Occupation of head of household } \\
\hline Cultivation & $470(57.2)$ & $520(56.5)$ & $990(56.8)$ \\
\hline Agricultural wage labourers & $314(38.2)$ & $122(13.3)$ & $436(25.7)$ \\
\hline Wage/salary labourers & $38(4.6)$ & $279(30.3)$ & $312(17.5)$ \\
\hline \multicolumn{4}{|l|}{ Education of head of household } \\
\hline No formal education & $182(22.1)$ & $609(66.1)$ & $791(44.1)$ \\
\hline Primary & $378(46.0)$ & $239(26.0)$ & $617(35.9)$ \\
\hline Secondary & $189(23.0)$ & $60(6.5)$ & $249(14.8)$ \\
\hline Higher Secondary/tertiary & $73(8.9)$ & $13(1.4)$ & $86(5.2)$ \\
\hline \multicolumn{4}{|l|}{ Landholding size } \\
\hline Landless & $306(37.2)$ & $153(16.6)$ & $459(26.3)$ \\
\hline Marginal (< 1 ha) & $83(10.1)$ & $743(80.7)$ & $826(47.4)$ \\
\hline Small (1 - < 2 ha) & $213(25.9)$ & $20(2.2)$ & $233(13.4)$ \\
\hline Semi-medium $(2-<4$ ha $)$ & $155(18.9)$ & $5(0.5)$ & $160(9.2)$ \\
\hline Medium $>4$ ha) & $65(7.9)$ & - & $65(3.7)$ \\
\hline \multicolumn{4}{|l|}{ Amount of money spent on food monthly (Rs.) } \\
\hline$<1000$ & $35(4.3)$ & $285(30.9)$ & $320(18.4)$ \\
\hline 1000 to $<2000$ & $315(38.3)$ & $509(55.3)$ & $824(47.3)$ \\
\hline 2000 to $<3000$ & $338(41.1)$ & $101(11.0)$ & $439(25.2)$ \\
\hline
\end{tabular}


Table 1 (continued)

\begin{tabular}{|c|c|c|c|}
\hline Demographic and socio-economic characteristics & Wardha $N^{*}(\%)$ & Koraput $N^{*}(\%)$ & Total for both districts $N^{*}(\%)$ \\
\hline$>=3000$ & $134(16.3)$ & $26(2.8)$ & $160(9.1)$ \\
\hline \multicolumn{4}{|c|}{ Decision on amount of money spent on food and types of food purchased } \\
\hline Husband/wife (joint) & $672(81.7)$ & $621(67.4)$ & $1292(74.2)$ \\
\hline Respondent & $126(15.3)$ & $183(19.9)$ & $309(17.7)$ \\
\hline Spouse/partner & $24(3.0)$ & $117(12.7)$ & $141(8.1)$ \\
\hline \multicolumn{4}{|l|}{ Farm animals } \\
\hline Yes & $454(55.2)$ & $655(71.1)$ & 1109 (63.6) \\
\hline No & $368(44.8)$ & $266(28.9)$ & $639(36.4)$ \\
\hline \multicolumn{4}{|l|}{ Traditional homestead gardening } \\
\hline Yes & $124(15.1)$ & $446(48.1)$ & $570(32.7)$ \\
\hline No & $698(84.9)$ & $475(51.6)$ & $1173(67.3)$ \\
\hline \multicolumn{4}{|l|}{ Type and mix of horticultural crops } \\
\hline 1 & $62(50.0)$ & $114(25.6)$ & $176(37.8)$ \\
\hline 2 & $38(30.7)$ & $154(34.5)$ & $192(32.6)$ \\
\hline 3 & $14(11.3)$ & $93(20.9)$ & $107(16.1)$ \\
\hline 4 or more & $10(8.0)$ & $85(19.0)$ & $95(13.5)$ \\
\hline
\end{tabular}

$*_{N}$ indicates the total number of households, except for gender and age group, where $N$ indicates the total population. Figures in parenthesis indicate percentages

Among the $62.8 \%$ of households cultivating in the Kharif, only $14.9 \%$ also cultivated in the Rabi (cool dry) season. The Rabi land area was mostly occupied with sole-crop wheat $(54.6 \%)$, wheat intercropped with chick pea $(32.5 \%)$ and sole chick pea (13\%).

With respect to crop types in Koraput, of the 921 households, $83.4 \%$ of households cultivated Kharif season crops. Among Kharif growers, about $64.5 \%$ of farm-households cultivated rice (Fig. 2). Rice systems occupied most of the land, while some $(30.5 \%)$ households additionally cultivated a portion of upland area with finger millet or little millet. A very small percentage of farm-households $(5 \%)$ cultivated sole-crop or mixtures of horse gram, finger millet or little millet. Of the $83.4 \%$ households cultivating during the Kharif, only $23.3 \%$ households cultivated Rabi season crops. Rabi land area was predominately occupied with groundnut
Fig. 1 Kharif and Rabi cropping systems by farm households during the base year in Wardha

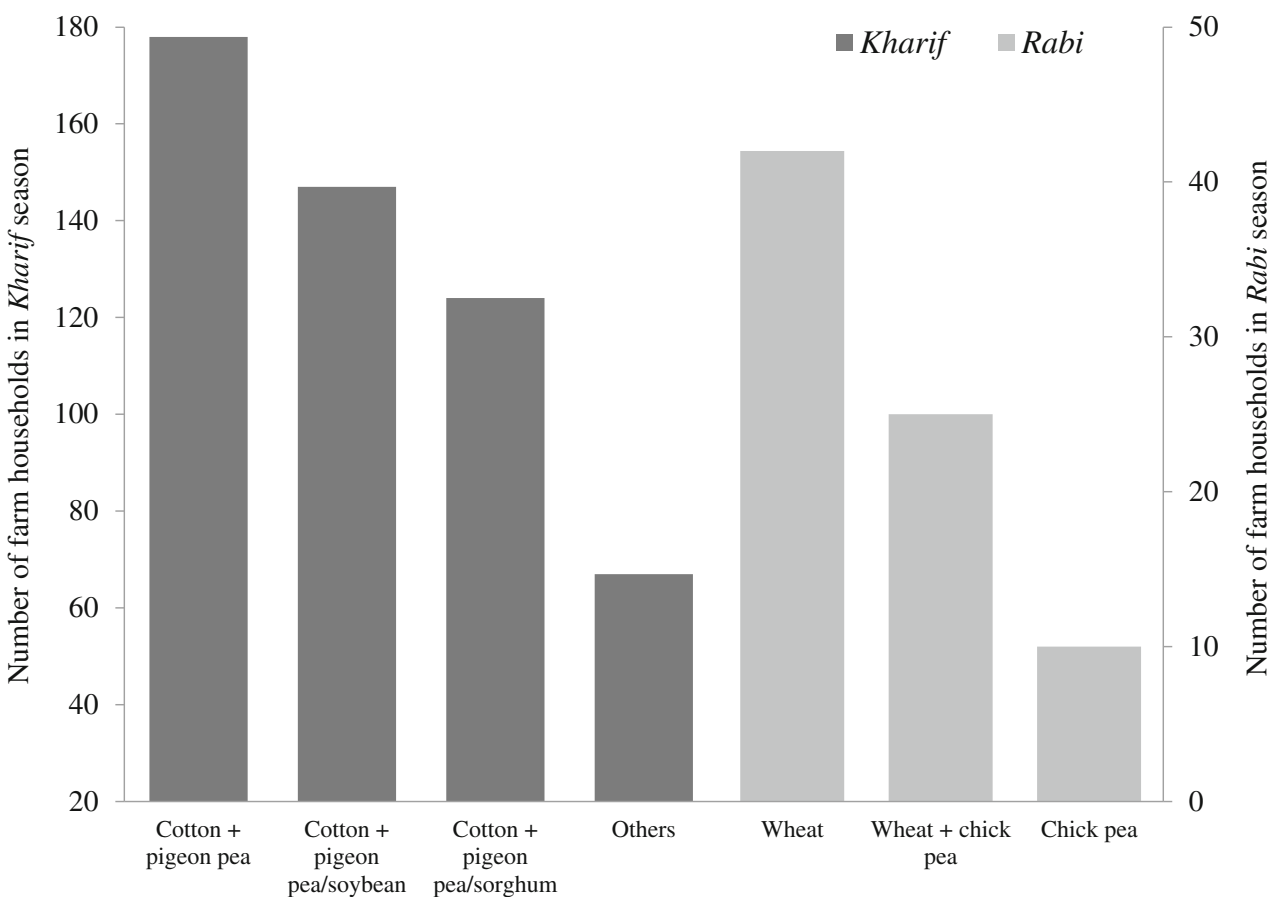


Fig. 2 Kharif and Rabi cropping systems by farm households during the base year in Koraput

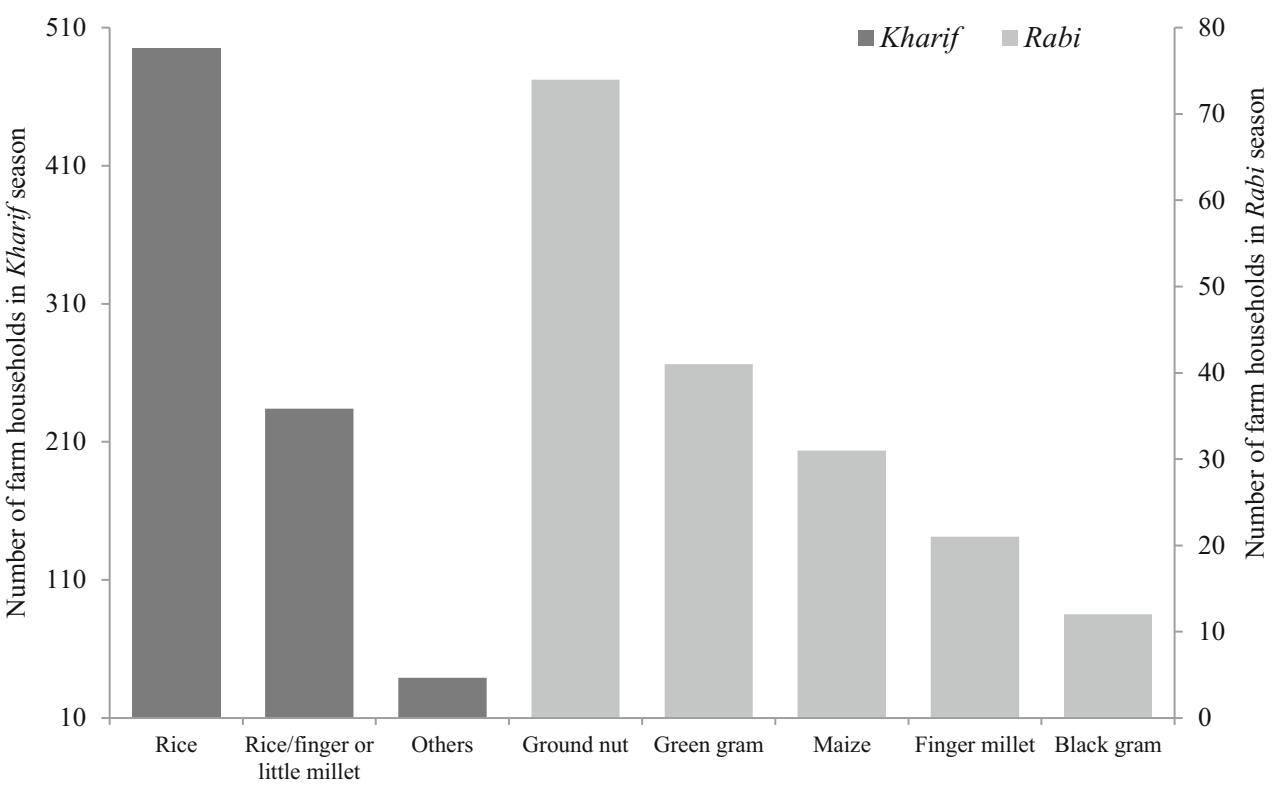

$(41.3 \%)$, green gram $(23 \%)$, maize $(17.3 \%)$, finger millet $(11.7 \%)$ and black gram $(6.7 \%)$.

\subsection{Anthropometric and biochemical measurements}

In both locations, more than $40 \%$ of children under age five were reported underweight (WAZ $<-2 \mathrm{SD}$ ), 35\% stunted (HAZ $<-2 \mathrm{SD}$ ) and about $27 \%$ wasted (WHZ $<-2 \mathrm{SD})$. In Koraput, $41.1 \%$ of school-age children (5-9 years) were reported undernourished (BMIZ <-2SD), in contrast to $33.1 \%$ in Wardha. However, in Wardha, $54.1 \%$ and $51.8 \%$ of adolescents (10-14 and 15-17 years) were undernourished (BMIZ < -2SD), in contrast to $29.5 \%$ and $17.5 \%$ in Koraput. In both locations, the percentage of women with CED (BMI < 18.5) (47\%) was found to be higher than for men (39\%). Table 2 gives the anthropometric and biochemical parameters of the study population.

The biochemical analysis indicated that, in both locations, about $33 \%$ of children under age five had VAD. About $65 \%$ of children under age five in Koraput and $73 \%$ in Wardha had anaemia. In Wardha, the majority (71.4\% and $73.3 \%$ ) of girls in the age groups of 12-14 and 15-17 years respectively reported anaemia while it was $58.8 \%$ and $64.4 \%$ for these age groups in Koraput. The percentage of non-pregnant non-lactating women with anaemia was $78.4 \%$ in Wardha, and a little lower at $64.8 \%$ in Koraput. In both Wardha and Koraput, 55$60 \%$ of pregnant women and $67-71 \%$ of lactating women were reported anaemic.

\subsection{Food consumption pattern and dietary diversity}

Tables 3 and 4 give the average per day consumption of different foods and the percentage of households consuming $<70 \%$ RDI of different food groups. The average intake of cereals and millets ranged from a low $323.1 \mathrm{~g}$ in Wardha to a high $563.9 \mathrm{~g}$ in Koraput. The consumption of rice was observed high in Koraput (509.6 g) with limited finger millet (77.3 g). In Wardha, the consumption of wheat $(233.3 \mathrm{~g})$ was high, followed by rice (113.1 g). Consumption of cereals and millets was at $>70 \%$ of RDI by $78.5 \%$ of households in Wardha and $96.6 \%$ in Koraput. The average consumption of

Table 2 Anthropometric and biochemical measurements of the study population in two villages in India

\begin{tabular}{|c|c|c|c|c|}
\hline \multirow[t]{2}{*}{ Indices } & \multicolumn{2}{|c|}{ Wardha } & \multicolumn{2}{|c|}{ Koraput } \\
\hline & $N \#$ & $\%$ & $N \#$ & $\%$ \\
\hline \multicolumn{5}{|l|}{ Anthropometric } \\
\hline $0-5$ years $(\mathrm{WAZ}<-2 \mathrm{SD})$ & 169 & 40.8 & 377 & 44.6 \\
\hline $0-5$ years $(\mathrm{HAZ}<-2 \mathrm{SD})$ & & 35.5 & & 35.0 \\
\hline $0-5$ years $(\mathrm{WHZ}<-2 \mathrm{SD})$ & & 27.8 & & 26.5 \\
\hline $5-9$ years $(\mathrm{BMIZ}<-2 \mathrm{SD})$ & 157 & 33.1 & 472 & 41.1 \\
\hline $10-14$ years $(\mathrm{BMIZ}<-2 \mathrm{SD})$ & 255 & 54.1 & 404 & 29.5 \\
\hline $15-17$ years $(\mathrm{BMIZ}<-2 \mathrm{SD})$ & 114 & 51.8 & 206 & 17.5 \\
\hline$>18$ years men $(\mathrm{BMI}<18.5)$ & 1072 & 39.2 & 1033 & 38.8 \\
\hline$>18$ years women $(\mathrm{BMI}<18.5)$ & 1002 & 47.8 & 1129 & 47.7 \\
\hline \multicolumn{5}{|l|}{ Biochemical } \\
\hline $1-5$ years children $(\mathrm{Hb}<11 \mathrm{~g} / \mathrm{dl})$ & 130 & 73.8 & 376 & 65.2 \\
\hline $12-14$ years girls $(\mathrm{Hb}<12 \mathrm{~g} / \mathrm{dl})$ & 70 & 71.4 & 153 & 58.8 \\
\hline $15-17$ years girls $(\mathrm{Hb}<12 \mathrm{~g} / \mathrm{dl})$ & 60 & 73.3 & 104 & 64.4 \\
\hline $18-45$ years women* $(\mathrm{Hb}<12 \mathrm{~g} / \mathrm{dl})$ & 500 & 78.4 & 667 & 64.8 \\
\hline Pregnant women $(\mathrm{Hb}<11 \mathrm{~g} / \mathrm{dl})$ & 18 & 55.6 & 51 & 60.8 \\
\hline Lactating women $(\mathrm{Hb}<12 \mathrm{~g} / \mathrm{dl})$ & 34 & 67.6 & 72 & 70.8 \\
\hline $\begin{array}{l}1-5 \text { years children (blood vitamin } \\
\mathrm{A}<20 \mu \mathrm{g} / \mathrm{dl} \text { ) }\end{array}$ & 135 & 34.1 & 386 & 33.4 \\
\hline
\end{tabular}

*non pregnant non lactating

\# $N$ indicates total population in the category 
Table 3 Average household consumption of foodstuffs ( $\mathrm{g}$ or $\mathrm{ml} /$ consumption unit/day) and individual dietary diversity score (DDS) in India

\begin{tabular}{|c|c|c|c|c|c|}
\hline \multirow[t]{2}{*}{ Categories } & \multirow[t]{2}{*}{ RDI\# } & \multicolumn{2}{|c|}{ Wardha } & \multicolumn{2}{|c|}{ Koraput } \\
\hline & & $N^{*}$ & Mean & $N^{*}$ & Mean \\
\hline Cereals and millets & 375 & 300 & 323.1 & 300 & 563.9 \\
\hline Rice & & 294 & 113.1 & 297 & 509.6 \\
\hline Wheat & & 327 & 233.3 & 8 & 103.4 \\
\hline Sorghum & & 5 & 170.8 & - & - \\
\hline Finger millets & & - & - & 253 & 77.3 \\
\hline Pulses and legumes & 75 & 300 & 61.1 & 300 & 34.7 \\
\hline Green leafy vegetables & 100 & 300 & 9.6 & 300 & 17.2 \\
\hline Roots and tubers & 200 & 300 & 29.9 & 300 & 103.6 \\
\hline Other vegetables & 200 & 300 & 33.4 & 300 & 85.4 \\
\hline Nuts and oil seeds & - & 300 & 1.9 & 300 & 0.9 \\
\hline Condiments and spices & - & 300 & 16.2 & 300 & 11.3 \\
\hline Fruits & 100 & 300 & 16.4 & 300 & 14.5 \\
\hline Fish and other sea foods & - & 300 & 2.2 & 300 & 11.0 \\
\hline Meat and poultry & - & 300 & 4.3 & 300 & 8.7 \\
\hline Milk and milk products & 300 & 300 & 27.8 & 300 & 6.5 \\
\hline Fats and edible oils & 25 & 300 & 23.7 & 300 & 10.8 \\
\hline Sugars and jaggery & 20 & 300 & 36.2 & 300 & 12.2 \\
\hline DDS & & 552 & 7.82 & 768 & 7.14 \\
\hline
\end{tabular}

* $N$ indicates number of households except in the case of DDS where it indicates numberof individuals

\# RDI Recommended Dietary Intake

pulses was $61.1 \mathrm{~g}$ in Wardha, but only $34.7 \mathrm{~g}$ in Koraput. The percentage of households consuming pulse-protein $<70 \%$ of RDI ranged from as high as $75.4 \%$ in Koraput to $40.5 \%$ in Wardha.

The average daily consumption of green leafy vegetables and fruits in Wardha and Koraput was well below the suggested level of $100 \mathrm{~g}$. Consumption of green leafy vegetables by more than $90 \%$ of households was $<70 \%$ of RDI. The

Table 4 Distribution (\%) of households according to level of food intake at $\mathrm{RDI}^{*}(<70 \%)$ in two villages in India

\begin{tabular}{lll}
\hline Categories & Wardha & Koraput \\
\hline Cereals and millets & 21.5 & 3.4 \\
Pulses and legumes & 40.5 & 75.4 \\
Green leafy vegetables & 95.5 & 90.3 \\
Roots and tubers & 98.7 & 76.3 \\
Other vegetables & 97.5 & 77.4 \\
Milk/milk products & 99.4 & 99.6 \\
Fruits & 95.5 & 94.0 \\
Fats and edible oils & 37 & 85.7 \\
Sugars/jaggery & 6.2 & 65.7 \\
\hline
\end{tabular}

* RDI Recommended Dietary Intake average consumption of root and tubers and other vegetables in Wardha and Koraput was well below the recommended level of $200 \mathrm{~g}$ per capita per day. Consumption of roots and tubers and other vegetables by more than $95 \%$ households in Wardha was at $<70 \%$ of RDI in contrast to $76.3 \%$ and $77.4 \%$ respectively in Koraput.

The average consumption of fish or other sea foods in Wardha and Koraput was $2.2 \mathrm{~g}$ and $11.0 \mathrm{~g}$ respectively. A similar intake pattern was observed for animal products. The average intake of milk and milk products in both the study areas was well below the RDI levels, with more than $99 \%$ of households consuming $<70 \%$ of RDI.

In Wardha, compared with RDI levels, the average consumption of sugar-related products was higher whilst that of fats and edible oils was comparable. The proportion of households with an intake of sugar-related products and fats and edible oils at $<70 \%$ of RDI was only $6.2 \%$ and $37 \%$ respectively. In contrast, in Koraput, the average consumption of sugar-related products and fats and edible oils was below the RDI levels with $65.7 \%$ and $85.7 \%$ of households consuming $<70 \%$ of the RDI of these products.

For food source, $76 \%$ of the households in Wardha reportedly sourced wheat and rice from the market and the remaining $24 \%$ from the public distribution system (PDS). ${ }^{3}$ In Koraput, about $43 \%$ of households consumed home-grown rice, $43 \%$ sourced it from the PDS and the remaining $14 \%$ from the market. The source for finger millet was reported as mainly market (70\%) and the remaining was home-grown $(30 \%)$. In both the study areas, most households reported the market as a major source of benefitting non-cereal foods.

\subsection{Relating socio-demographic variables and nutritional status}

Associations between demographic and socio-economic variables with individual anthropometric measurements revealed a statistically significant relationship with the dwelling and toilet types in both Wardha $\left(\chi^{2}=14.42, P<0.05\right.$; $\left.\chi^{2}=6.28, P<0.05\right)$ and Koraput $\left(\chi^{2}=13.88, P<0.05\right.$; $\left.\chi^{2}=18.51, P<0.05\right)$. In addition, in Wardha, cooking fuel $\left(\chi^{2}=7.69, P<0.05\right)$ and in Koraput, monthly expenses on food $\left(\chi^{2}=12.48, P<0.05\right)$, education of household heads $\left(\chi^{2}=14.61, P<0.05\right)$ and landholding size $\left(\chi^{2}=19.23\right.$, $P<0.05)$ were found to have statistically significant associations with individual anthropometric measurements.

Tables 5 and 6 show the relationship between sociodemographic variables and anthropometric measurements, based on student's t-test. In Wardha, the practice of open defecation had a significantly higher risk of underweight and

\footnotetext{
${ }^{3}$ PDS is a social protection measure of the Government of India to make available mainly staple food grains (rice and wheat), and sugar at a subsidised price to socio-economically weak households.
} 
Table 5 Relationship between socio-demographic variables and anthropometric measurements of children under age five in two villages in India

\begin{tabular}{|c|c|c|c|c|c|c|c|c|c|}
\hline & \multicolumn{3}{|c|}{$\mathrm{WHZ}<-2 \mathrm{SD}$} & \multicolumn{3}{|c|}{$\mathrm{HAZ}<-2 \mathrm{SD}$} & \multicolumn{3}{|c|}{$\mathrm{WAZ}<-2 \mathrm{SD}$} \\
\hline & Mean & $\pm \mathrm{SD}$ & $P$ & Mean & $\pm \mathrm{SD}$ & $P$ & Mean & $\pm \mathrm{SD}$ & $P$ \\
\hline \multicolumn{10}{|l|}{ Wardha } \\
\hline \multicolumn{10}{|l|}{ Toilet type } \\
\hline Open defecation & -1.48 & 1.13 & $0.00 *$ & -1.43 & 1.81 & 0.51 & -1.84 & 1.20 & $0.00 *$ \\
\hline Toilets & -0.58 & 1.84 & & -1.20 & 1.57 & & -1.05 & 1.85 & \\
\hline \multicolumn{10}{|l|}{ Types of cooking fuel } \\
\hline Firewood & -1.33 & 1.35 & 0.25 & -1.43 & 1.77 & $0.08^{*}$ & -1.73 & 1.38 & $0.04 *$ \\
\hline Gas & -0.73 & 1.00 & & -0.23 & 1.23 & & -0.65 & 1.04 & \\
\hline \multicolumn{10}{|l|}{ Koraput } \\
\hline \multicolumn{10}{|c|}{ Household heads education } \\
\hline No education & -1.61 & 1.19 & & -1.37 & 1.87 & & -1.88 & 1.42 & \\
\hline Secondary & -1.04 & 1.01 & $0.00 *$ & -0.65 & 1.78 & $0.01 *$ & -1.13 & 1.25 & $0.00 *$ \\
\hline
\end{tabular}

Significance at $* P<0.05$

wasting among children below five years of age and CED in adults. Wood-fire cooking had a significantly higher risk of underweight and stunting among children below five years and CED in adults. The kutcha house type had significantly higher risk of reduced BMI in school-age children, adolescents and adults. In Koraput, household heads with no formal

Table 6 Relationship between socio-demographic variables and anthropometric measurements of school-age children and adolescents $(6$ to 17 years) and adults ( $>=18$ years)

\begin{tabular}{|c|c|c|c|c|c|c|}
\hline & \multicolumn{3}{|c|}{ BMIZ $<-2$ SD } & \multicolumn{3}{|c|}{$\mathrm{BMI}<18.5$} \\
\hline & Mean & $\pm \mathrm{SD}$ & $P$ & Mean & $\pm \mathrm{SD}$ & $P$ \\
\hline \multicolumn{7}{|l|}{ Wardha } \\
\hline \multicolumn{7}{|l|}{ Toilet type } \\
\hline $\begin{array}{l}\text { Open defecation } \\
\text { Toilets }\end{array}$ & $\begin{array}{l}-1.99 \\
-1.98\end{array}$ & $\begin{array}{l}1.11 \\
1.16\end{array}$ & 0.91 & $\begin{array}{l}19.19 \\
20.0\end{array}$ & $\begin{array}{l}2.89 \\
3.60\end{array}$ & $0.00 *$ \\
\hline \multicolumn{7}{|c|}{ Types of cooking fuel } \\
\hline $\begin{array}{l}\text { Firewood } \\
\text { Gas }\end{array}$ & $\begin{array}{l}-1.98 \\
-2.19\end{array}$ & $\begin{array}{l}1.12 \\
0.96\end{array}$ & 0.57 & $\begin{array}{l}19.33 \\
20.63\end{array}$ & $\begin{array}{l}3.08 \\
3.26\end{array}$ & $0.00 *$ \\
\hline \multicolumn{7}{|l|}{ Dwelling type } \\
\hline $\begin{array}{l}\text { Semi-pucca } \\
\text { Kutcha }\end{array}$ & $\begin{array}{l}-1.90 \\
-2.10\end{array}$ & $\begin{array}{l}1.09 \\
1.15\end{array}$ & $0.04 *$ & $\begin{array}{l}19.63 \\
19.21\end{array}$ & $\begin{array}{l}3.12 \\
3.05\end{array}$ & $0.02 *$ \\
\hline \multicolumn{7}{|l|}{ Koraput } \\
\hline \multicolumn{7}{|c|}{ Amount of money spent on food monthly (Rs.) } \\
\hline $\begin{array}{l}<1000 \\
>=3000\end{array}$ & $\begin{array}{l}-1.59 \\
-1.38\end{array}$ & $\begin{array}{l}0.97 \\
0.95\end{array}$ & $0.03 *$ & $\begin{array}{l}18.95 \\
19.50\end{array}$ & $\begin{array}{l}2.39 \\
3.12\end{array}$ & $0.00 *$ \\
\hline \multicolumn{7}{|c|}{ Household heads education } \\
\hline $\begin{array}{l}\text { No education } \\
\text { Primary }\end{array}$ & $\begin{array}{l}-1.51 \\
-1.61\end{array}$ & $\begin{array}{l}1.06 \\
1.05\end{array}$ & 0.19 & $\begin{array}{l}18.81 \\
19.31\end{array}$ & $\begin{array}{l}2.21 \\
2.60\end{array}$ & $0.00^{*}$ \\
\hline Secondary & -1.57 & 1.04 & 0.66 & 20.19 & 3.59 & $0.00^{*}$ \\
\hline \multicolumn{7}{|l|}{ Dwelling type } \\
\hline $\begin{array}{l}\text { Semi-pucca } \\
\text { Kutcha }\end{array}$ & $\begin{array}{l}-1.53 \\
-1.55\end{array}$ & $\begin{array}{l}0.98 \\
1.12\end{array}$ & 0.78 & $\begin{array}{l}19.43 \\
18.81\end{array}$ & $\begin{array}{l}2.92 \\
2.18\end{array}$ & $0.00 *$ \\
\hline
\end{tabular}

Significance at $* P<0.05$ education had a higher risk of household members being undernourished. Similarly, the lesser the amount of household expenditure on food showed a significantly higher risk of reduced BMI in school-age children, adolescents and adults.

Examining the association of demographic and socioeconomic variables with biochemical measurements revealed a statistically significant relationship with monthly expenses on food $\left(\chi^{2}=11.36, P<0.05\right)$ and education level of head of household $\left(\chi^{2}=28.08, P<0.05\right)$ in Wardha. In Koraput, the dwelling type $\left(\chi^{2}=6.80, P<0.05\right)$, source of drinking water $\left(\chi^{2}=13.25, P<0.05\right)$ and occupation of household head $\left(\chi^{2}=21.23, P<0.05\right)$ were found to have statistically significant associations with biochemical measurements of children under age five and adolescent girls and women aged 12 to 45 years.

Table 7 shows the association between socio-demographic variables and anaemia, based on student's t-test. In Wardha, mean haemoglobin levels were found to be significantly lower (or higher prevalence of anaemia) for children in households spending less than Rs. 3000 per month on food. Heads of households having no formal education had statistically significantly lower mean haemoglobin levels for children under age five and adolescent girls and women aged 12 to 45 years. In Koraput, children under age five, adolescent girls and women aged 12 to 45 years in kutcha-type households, sourcing drinking water from a tube-well and also occupation of the household head in wage and salary labour were found to have statistically significantly lower mean haemoglobin levels. In both study areas, mean haemoglobin levels were found to be less than the WHO cut-offs.

\subsection{Relating nutrition status and DDS}

In both the study areas, a statistically significant association was found to exist only between DDS and BMI of adults 
Table 7 Relationship between socio-demographic variables with haemoglobin levels of children ( $<5$ years) and adolescent girls and women (12 to 45 years) in India

\begin{tabular}{|c|c|c|c|c|c|c|}
\hline & \multicolumn{3}{|c|}{$\begin{array}{l}\text { Haemoglobin } \\
\text { level (children } \\
\text { under age 5) }\end{array}$} & \multicolumn{3}{|c|}{$\begin{array}{l}\text { Haemoglobin level } \\
\text { (12 to } 45 \text { years girls } \\
\text { \& women) }\end{array}$} \\
\hline & Mean & $\pm \mathrm{SD}$ & $P$ & Mean & $\pm \mathrm{SD}$ & $P$ \\
\hline \multicolumn{7}{|l|}{ Wardha } \\
\hline \multicolumn{7}{|c|}{ Amount of money spent on food monthly (Rs.) } \\
\hline $\begin{array}{l}1000 \text { to } 2000 \\
>=3000\end{array}$ & $\begin{array}{l}9.47 \\
10.15\end{array}$ & $\begin{array}{l}1.66 \\
1.52\end{array}$ & $0.03 *$ & $\begin{array}{l}10.62 \\
10.82\end{array}$ & $\begin{array}{l}1.69 \\
1.94\end{array}$ & 0.22 \\
\hline \multicolumn{7}{|c|}{ Education of head of household } \\
\hline $\begin{array}{l}\text { No education } \\
\text { Primary }\end{array}$ & $\begin{array}{l}9.1 \\
9.75\end{array}$ & $\begin{array}{l}2.03 \\
1.51\end{array}$ & 0.15 & $\begin{array}{l}10.23 \\
10.77\end{array}$ & $\begin{array}{l}1.86 \\
1.81\end{array}$ & $0.00 *$ \\
\hline Secondary & 10.00 & 1.43 & $0.04 *$ & 10.73 & 1.91 & $0.02 *$ \\
\hline \multicolumn{7}{|l|}{ Koraput } \\
\hline \multicolumn{7}{|c|}{ Occupation of head of household } \\
\hline $\begin{array}{l}\text { Cultivation } \\
\text { Non-agricultural wage } \\
\text { Labour }\end{array}$ & $\begin{array}{l}10.27 \\
9.95\end{array}$ & $\begin{array}{l}1.67 \\
1.36\end{array}$ & 0.12 & $\begin{array}{l}11.45 \\
10.85\end{array}$ & $\begin{array}{l}1.68 \\
1.59\end{array}$ & $0.00^{*}$ \\
\hline $\begin{array}{l}\text { Agriculture wage } \\
\text { Labour }\end{array}$ & 10.20 & 1.50 & 0.78 & 10.56 & 1.98 & $0.00^{*}$ \\
\hline \multicolumn{7}{|l|}{ Source of drinking water } \\
\hline $\begin{array}{l}\text { Piped water } \\
\text { Dug /tube-well }\end{array}$ & $\begin{array}{l}10.53 \\
10.19\end{array}$ & $\begin{array}{l}1.89 \\
1.51\end{array}$ & 0.16 & $\begin{array}{l}11.61 \\
11.14\end{array}$ & $\begin{array}{l}1.48 \\
1.74\end{array}$ & $0.00^{*}$ \\
\hline \multicolumn{7}{|l|}{ Dwelling type } \\
\hline $\begin{array}{l}\text { Semi-pucca } \\
\text { Kutcha }\end{array}$ & $\begin{array}{l}10.41 \\
10.10\end{array}$ & $\begin{array}{l}1.48 \\
1.62\end{array}$ & $0.05 *$ & $\begin{array}{l}11.35 \\
11.06\end{array}$ & $\begin{array}{l}1.67 \\
1.75\end{array}$ & $0.01 *$ \\
\hline
\end{tabular}

Significance at $* P<0.05$

( $>18$ years) as seen from Table 8 , indicating that mean BMI significantly $(P<0.05)$ decreased as the DDS decreased from high to medium to low in Wardha and from high to low in Koraput. Only in Koraput, a statistically significant relationship $(P<0.05)$ was found between DDS and haemoglobin levels of adolescent girls and women aged 12 to 45 years, implying significantly lower haemoglobin levels (higher prevalence rate of anaemia) in this category, as the DDS decreased from high to low.

\section{Discussion}

In 2012, both Koraput and Wardha figured in the coverage list of the multi-stakeholder nutrition programme for districts with a high burden of malnutrition announced by the Ministry of Women and Child Development, Government of India.

Nutritional status of children under age five is a key indicator for the assessment of household food security. Taking into account different indicators of under-nutrition, the more than $40 \%$ underweight (low weight for age), 35\% stunting (low height for age) and about $27 \%$ wasting (low weight for height) we found among children under age five in the study areas appears unacceptably high. Similar observations of high rates of child undernutrition among the rural population in India were reported by Sathyanath and Rashmi (2013), and Gragnolati et al. (2005). Childhood under-nutrition directly affects the development of children by retarding physical and mental development, increases susceptibility to infections, and diminishes intellectual ability and work capacity (Caulfield et al. 2006). The prevalence rate of under-nutrition in school-age children (5-9 years) was found to be higher in Koraput than in Wardha; the proportion of undernourished adolescents (10-14 and 15-17 years) was higher in Wardha. The overall nutritional status of adult men and women in the survey area also indicated a serious problem: $39 \%$ of the men and $47 \%$ women suffered from CED, with the proportion higher among women. This observation supports del Ninno et al. (2001) that women in many poor economies are more caloriedeficient and often suffer from CED, as compared to men.

Our study indicates a higher prevalence rate of anaemia in children under five years of age, girls (12-17 years), women (18-45 years) and pregnant women. Iron-deficiency anaemia, especially during pregnancy, is reportedly associated with maternal mortality, preterm labour, low birth-weight, and infant mortality (Zimmermann and Hurrell 2007). Moreover, irondeficiency affects child cognitive and motor development and is a serious contributor to childhood morbidity (Baker and Greer 2010). As high as $33 \%$ of children overall were found with VAD. VAD is generally associated with decreased dietary intake of preformed vitamin A and its precursors, together with a high prevalence of infectious diseases (WHO 2009). In

Table 8 Relationship between nutrition status and dietary diversity score (DDS) in two villages in India

\begin{tabular}{|c|c|c|c|c|c|c|c|c|}
\hline & \multicolumn{2}{|c|}{ Low dietary diversity } & \multicolumn{3}{|c|}{ Medium dietary diversity } & \multicolumn{3}{|c|}{ High dietary diversity } \\
\hline & Mean & $\pm \mathrm{SD}$ & Mean & $\pm \mathrm{SD}$ & $P$ & Mean & $\pm \mathrm{SD}$ & $P$ \\
\hline \multicolumn{9}{|l|}{ Wardha } \\
\hline $\mathrm{BMI}>=18$ years & 19.33 & 3.03 & 19.39 & 3.02 & $0.045^{*}$ & 20.06 & 2.92 & $0.01 *$ \\
\hline \multicolumn{9}{|l|}{ Koraput } \\
\hline $\mathrm{BMI}>=18$ years & 18.80 & 2.18 & 19.18 & 2.22 & 0.12 & 19.66 & 3.12 & $0.00^{*}$ \\
\hline Haemoglobin level (12 to 45 years girls \& women) & 10.76 & 1.68 & 11.40 & 1.66 & 0.83 & 11.34 & 1.41 & $0.02^{*}$ \\
\hline
\end{tabular}

Significance at $* P<0.05$ 
general, evidence of high incidence of under-nutrition and micronutrient deficiency among the rural population in both Wardha and Koraput is of concern, thus reiterating the need for multi-sectoral nutrition interventions.

\subsection{Socio-demographic and nutritional status}

Previous studies have reported that socio-economic and sociodemographic variables have substantial influence on undernutrition (Sen and Mondal 2012; Frongillo et al. 1997). In the present study, the socio-economic backwardness of the surveyed indigenous populations was visually evident in their dwelling conditions. Overall, kutcha houses made up of straw roof and mud walls were the most common types. Access to clean and safe drinking water contributes to improved nutrition status (Leipziger et al. 2003). UNICEF/WHO (2015) considers protected water supplies from piped/tap water and tubewells as safe for drinking, while the other unimproved sources are considered as unsafe. Going by this classification, only $52 \%$ of households in Wardha and 66\% in Koraput have access to safe drinking water. Further, most households in Koraput do not have information about whether tube-wellsourced drinking water is free from arsenic. Lack of improved environmental sanitation and hygiene is the main cause of excreta-related diseases such as diarrhoea and cholera, and also under-nutrition (UNICEF/WHO 2015; Spears 2013). Most households in the study areas were found to practice open defecation. Indoor air-pollution due to use of solid fuels is the second most critical environmental risk factor after poor water and sanitation, contributing to numerous respiratory diseases (Bruce et al. 2006). Among surveyed households, wood fire was the most popular source of domestic energy used for cooking. This was largely due to its availability and inexpensive nature, and also lack of access to contemporary cooking fuels. Looking at these socio-demographic variables, no single factor with a high influence for under-nutrition could be isolated. In general, substandard living conditions of the surveyed households reflected a higher risk of household members to under-nutrition and micronutrient deficiency.

Most household members were of working age (18 to 44 years), indicating the potential for labour-intensive agriculture. The majority of households were nuclear or extended nuclear families signifying increased disintegration of the traditional joint family. Two major factors contributing to an increase in nuclear families included resource scarcity (e.g. food, income) and a problem of lack of space for accommodation. Levels of education determine the ability of a household to access income and have positive impacts on various aspects of health and wellbeing (Schultz 1988). Looking at the surveyed household heads, most either had no education or were educated only to the primary level. This was consistent even for other household members in the study areas. The heads of households with no formal education in Koraput and some primary level of education in
Wardha showed significantly higher risks of under-nutrition and micronutrient deficiency among household members. Sandiford et al. (1997) also reported that illiterate household heads showed significantly higher risks of under-nutrition, particularly wasting among children in their households.

Other determinants of under-nutrition were the occupation of household heads and amount of money spent on food. Occupation of household heads as casual labourers or daily wage earners (viewed as a low productive activity as it provides workers with just a basic income for survival) showed significantly higher risk of under-nutrition and micronutrient deficiency. In addition, they reportedly migrate temporarily to nearby areas especially during the Rabi (dry) season for employment opportunities to diversify income. According to Webb and Block (2012), the amount of money spent on food has a direct relationship with the nutritional status of household members. In both study areas, the lesser the amount of money spent on food indicated less access to food, and thus significantly higher risk of under-nutrition and micronutrient deficiency. Overall, in both study locations, socio-economic and socio-demographic variables indicated the lack of basic social infrastructure and low human development with very poor welfare indices.

\subsection{Agriculture, nutrition, and their disconnect}

The two main agricultural seasons in the areas are the Kharif and Rabi. Kharif cropping is conducted from June to October correlating with the southwest monsoon (June to September) and hence assured rainfall. Each year more than $80 \%$ of total rainfall is received from the southwest monsoon (Prasanna 2014). However, uncertainty in the distribution of monthly rainfall patterns (above- or below-normal rains) results in positive or negative effects on cropping and yield performance. Rabi cropping is from November to March, involving cool and dry season crops. These crops are usually grown using residual soil moisture after the southwest monsoon, and with supplementary irrigation. More often than not, low soil moisture affects the sowing of seeds. Terminal drought is a major production constraint, as crops are highly sensitive during later growth stages. In both of the study areas, rain-fed agriculture (Kharif) is widely practiced. Although farmhouseholds cultivated in the Rabi, the area planted was very limited, because of a lack of water and irrigation facilities. Variable amounts of crop-saving irrigation is always required to avoid crop failures in the Rabi season. Captive water (e.g. tube well) is the only form available for irrigation in the study locations. Thus the livelihood and economy of farmers is highly influenced by spatio-temporal variability of rainfall.

Typically, farmers depended only on local varieties of crops based on their Kharif season characteristics. If the onset of rain was early or normal, then local late maturing varieties were preferred. If rains started late, early maturing varieties were preferred to maintain potential yield. The surveyed farm- 
households had experienced and managed complex and heterogeneous environments to cultivate rain-fed crops using their indigenous knowledge in the past. But recent reported abrupt changes to the local climate (Birthal et al. 2014), indicated by fluctuating air temperatures and precipitation, has substantially affected local weather and impacted Kharif crop production. In addition, under marginal growing conditions, local crop varieties have resulted in a loss of competitiveness and lower productivity levels. Limitations identified in our survey, as also reported in many rural agricultural settings (e.g. Bergamini et al. 2013; Altieri et al. 2015; Snapp et al. 2010), such as the neglect of several naturally-fortified and drought-tolerant food crops, the use of old types of seed and outdated agronomic practices, a focus on repetitive cropping patterns, insufficient crop diversification and declining soil fertility pose greater challenges for successful crop yields with variable weather conditions. Similar to the observations of Gonzalez (2015), most of our surveyed farm-householders perceived climate risk scenarios to be a natural process, rather than a consequence of human activity. Overall, the lack of technology and knowledge transfer in conjunction with inadequate adjustments to crop management and inappropriate farm-level resilience and adaptation strategies to environmental perturbations are the main reasons for the inadequate farming situation, worsening food and nutrition security in our study villages; these also posed a serious risk of undermining the livelihoods of farm households.

Farm-households in Koraput and Wardha varied substantially in their landholding size and the choice of farming practices. In Koraput, the existing cropping pattern reflected a predominance of subsistence cropping. The soils of Koraput are red loamy and red sandy soils, ideal for rice cultivation (State Agriculture Policy 2013). The principal crop in the Kharif season was rice with very limited millets, and in the Rabi season, groundnut, green gram, maize, finger millet and black gram were grown, occupying very limited areas. Finger millet has been reportedly reliable and resilient to weather aberrations. Most were marginal farmers with farm landholdings less than one ha, often less than an acre ( 1 acre is equivalent to 0.40 ha or $4047 \mathrm{~m}^{2}$ ). The small land areas owned by farm-households appeared highly uneven, sloped and undulated, and were often fragmented into lowland, medium land and upland across the village. We observed that the restricted and asymmetric farm size resulted in a shortage of farmland for some crop husbandry practices, limiting production and also the economic potential. Although households depended more on home-grown foods than from markets, other challenges (also reported in State Agriculture Policy 2013) included geographical remoteness, absence of adequate credit, and a shortage of technological inputs coupled with marketing risk when growing other crops. Many of these factors contribute to the existing conservative approaches to cropping. In view of the very limited landholdings by most marginal farmers, a lack of access to off-farm income was the reason reported by farmers for not being able to overcome food shortages or to access non-cereal foods, as evidenced from the household food intake patterns we found.

Unlike Koraput, Wardha was dominated by small and semi-medium farmers, but the percentage of landless persons appeared very high. The landless population depends on multiple inconsistent sources to sustain their livelihood and hence are more prone to recurrent food shortages. The soil of Wardha is characterised by black clayey or loamy soils and stony shallow black soils that are highly suitable for cultivation of cotton. The principal crops in the Kharif season were Bt-cotton + pigeon pea, with limited soybean and sorghum. In the Rabi season, household food security crops like sole wheat, wheat + chick pea and sole chick pea occupying very limited areas were grown. The existing cropping pattern indicated mostly high input- and high output-based commercial or cash cropping. The potential for high value crops and easy market access for their produce heavily contributed to the observed pattern of cultivating cash crops (Gavali et al. 2011). Most of the wheat and rice consumed by households came from the market and the PDS. This has extensively limited the area of production and consumption of naturallyfortified millets and sorghum, which were the preferred staple foods until about two decades ago (Gali and Parthasarathy Rao 2012). Additionally, dependence on supplies of food grains from elsewhere and markets cause households to be more vulnerable to food insecurity (Huang et al. 2017), especially when there is a fall in income during times of hardship (e.g. crop failures due to biotic or abiotic stressors or crop damage by wild animals). The observed deficit in household consumption of calories and other non-cereals is evidence of inconsistent household income per capita.

Overall, most surveyed households owned farm animals (a type of capital asset) and practiced combined crop-livestock farming. Among farm animals, cows were important as they produce milk of high nutritional value. In addition, livestock directly support agriculture through manure and draught power; whereas small animals, particularly poultry, generate income from eggs and meat. Most households reported that animal food products were not a significant part of their diet. Hence, household consumption of meat and poultry, and milk and milk products was found to be well below the RDI levels, indicating negligible animal-sourced food in the diets. Though farm animals are viewed mostly as a source of income, cash from animal sales was often not used for shifting household diet habits to include other food groups such as multi-nutrition-rich fruits and vegetables as observed by household food consumption patterns. Our surveyed farm-households reported that the cash generated was used for either medical emergencies or other planned expenditures (e.g., marriage), as common in resource-poor communities. Nevertheless, no access to animal health services for ruminant livestock and a higher incidence of Ranikhet disease in poultry were identified as reasons for lower economic returns. 
Previous studies have shown that an effectively designed homestead garden contributes to improved household diet and nutrition and is also an added source of income (Masset et al. 2011). Considering fruits and vegetables are often expensive to buy in markets, potentially restricting rural households' affordability, homestead gardens are viewed as a viable option for the enrichment of diets (Galhena et al. 2013). In both Wardha and Koraput, traditional gardening was practiced adjacent to the household settlement. Household food preferences and local availability of input materials largely determined the type and mix of fruit and vegetable crops grown. Based on water availability, gardening was practiced either throughout the year or limited only to the Kharif season. Challenging factors reported in our survey such as seed availability, water shortage, poor management and inadequate technological inputs hindered garden production and productivity levels to a large extent. Identified production constraints were evidenced when examining household food intake, with consumption of fruits by more than $94 \%$ of the households in both Wardha and Koraput being less than $70 \%$ of RDI levels. Similarly, consumption of root and other vegetables by more than $95 \%$ households in Wardha and $76 \%$ in Koraput was less than $70 \%$ of RDI. Most surveyed households despite having backyard space did not practice homestead gardening due to limited resource availability and lack of institutional support.

Both the study areas have a monotonous dietary pattern with just one or two major food groups, 24-h recall data were used to measure dietary diversity as it seems more reliable and precise (Oshaug 1997; Chavaz and Huenemann 1984), and low dietary diversity is often reported the key cause of under-nutrition and micronutrient deficiency (Ruel 2002; Shetty 2009). This is also evidenced from our study findings where DDS indicating low, homogeneous and poor dietary diversity contributed to increasing anaemia rates in adolescent girls and women in Koraput, and CED in adults ( $>18$ years) in both Koraput and Wardha. Generally, other mediating factors (e.g. hygiene and sanitation) being favourable, dietary diversity improves the nutritionabsorption rate of the individuals and thus may have beneficial health effects (WHO \& FAO 2003).

In Koraput, despite a higher intake of calories than the RDI levels, a higher prevalence of under-nutrition was observed, implying that calorie expenditure exceeds calorie intake. That negative energy balance causing under-nutrition might be due to the significant high amounts of energy spent in farming and other household activities, as compared to the energy intake, besides very limited intake of other non-cereal foods. Woo et al. (1985) also reported that energy expenditure increased by increasing the time spent in physical activity, as compared to calorie intake. In Wardha, although iron intake was comparable with RDI levels, a higher prevalence of iron-deficiency anaemia was witnessed, indicating lower absorption rates of iron. With wheat being a staple food, iron absorption may be potentially inhibited by phytates, as reported by Garcia-Casal et al.
(1998). A similar situation was also reported in the rural population in Iran, where high iron-deficiency anaemia was found despite the diet including high iron intake with wheat as a staple food (Haghshenass et al. 1972). Other reasons for a high prevalence of under-nutrition and micronutrient deficiency in both of our study areas were mostly due to diets with few animal products, fruits and vegetables. Grillenberger et al. (2006) reported that household diets containing few animal products, fruits and vegetables and predominantly consisting of cereals and legumes is associated with not only low intakes of several vitamins and minerals and poor mineral bio-availability, but also simultaneous deficiencies of multiple nutrients.

Variation observed in choice of farming orientation (commercial or subsistence), possession of animal components and practice of traditional homestead gardening between Wardha and Koraput, however, did not reflect major differences in the mean DDS and under-nutrition or even micronutrient deficiency status. Although DDS indicated seven food groups as a part of the individual diet, household food consumption patterns showed that the proportion of food intake from each food group was well below the RDI levels. As reported by Global Panel (2015) and also evident from the present findings, when farm-households move from subsistence-based to mostly cash-based commercial cropping, dietary patterns do not necessarily shift in the desired direction of high dietary quality and diversity. High intake of sugar and fat observed in commercial-crop-dominated Wardha rather than a more diversified food basket substituting often consumed staples, is indicative of spending of income from the sale of commercial crops. Furthermore, some food commodities, especially fruits and vegetables purchased post farm gate, are reportedly costlier than those produced within the farm. The overall scenario indicates a major disconnect of agriculture-nutrition linkages. Food and diets lacking diversity and without nutrition-focused farming systems including boosting income through commercial cropping (solely indirect effects) or monotonous diet by subsistence farming (solely direct effects) may not be appropriate to improve household nutrition and health status. A combination of innovative and integrated agriculture-nutrition strategies that can potentially diversify diet (directly) and better use of income generated for nutrition adequacy (indirectly), concurrently with other interventions to improve education, health, sanitation and household infrastructure stand a better chance of combating the under-nutrition and micronutrient deficiency problems (Das et al. 2014). We present some of these opportunities as ways forward in the remaining section.

\section{Conclusion and way forward}

Overall, the nutritional status, dietary diversity and cropping patterns in both Wardha and Koraput reflected the influence of local socio-economic and environmental aspects, farmhousehold decision making and the choice and opportunities 
of farming approaches. Our survey findings indicated several areas for action to improve household food and nutrition security. Establishing FSN (nutrition-sensitive agriculture) to improve household dietary diversity and income was the central objective of the present study. From the identified disconnect between agriculture and human nutrition, the FSN study identified potential routes to effectively overcome food and nutrition insecurities such as changes in crops (use of more naturally or bio-fortified crops); improvement of farming practices (that can enhance productivity, diversify crops and conserve soils); interconnection with animal components, including the conduct of animal health camps (for de-worming and vaccination) emphasizing disease preventive strategies; greater access to technologies and inputs through institutional and market linkages; promotion of homestead gardening (including rain water harvesting); and sustainable farm business models (processing and storage), especially for the landless.

Women are central to rural economies as witnessed by their co-participation in household decision making and in farm activities. Women are frequently recognised as catalytic agents against hunger and their sensitisation with nutrition education and training to increase women - centred backyard gardening or animal components will straightaway improve household diets and nutrition outcomes with additional access to income.

Water is crucial in these food vulnerable areas. Improving access to water, linked with improved agronomy including seed, fertilizers and technology will stabilise crop production. Agricultural water management is important to reduce poverty, optimise yield and income stability with additional benefits in improvement of nutritional status, health and societal equity (Valipour 2015; Yannopoulos et al. 2015). To increase the number of 'green' days and cropping intensity and to encourage more households to practice Rabi cropping, MSSRF is leveraging extant government schemes, such as lift and drip irrigation and watershed development. Identified areas in our survey that need increased attention include watershed management, de-silting and deepening of water bodies to recharge underground water resources, digging 'Jalkund' (rainwater collection and storage through ponds/pits) and microirrigation using drip/sprinkler systems. Other considerations may include non-conventional water resources such as treated wastewater to supplement irrigated agriculture, as the volume of non-treated discharged wastewater in India is reportedly very high (Valipour and Singh 2016). Such efforts will potentially enhance the livelihoods and nutrition of small and marginal farmers in the future.

To effectively operationalise the FSN approach (see Fig. 3), farm-households need to be engaged in planning, and jointly work with other stakeholders to identify key FSN interventions. FSN has to be tailored to the local socio-economic situation, cropping systems and weather risks, farm-household requirements, institutional support and policy and programme environment. To ensure sustainable and long-term adoption and outcomes of FSN, households need to witness interim benefits from each intervention activity in terms of improved food and nutrition security and increasing productivity. Our attention in planning is on production-consumption-nutrition links to ensure healthy diets through food diversity. This will potentially address major nutritional problems experienced by the surveyed households. Our field-level investigators will monitor and measure the experiences of each implemented FSN intervention with oversight from experts, and the understanding that changes to nutritional status will be the very last to be affected, in the process, identifying barriers and motivation for early adapters or innovators. Comparison with the present baseline survey findings for each activity will provide necessary evidence for supporting multi-level policy dialogues. In addition to proposed FSN strategies,
Fig. 3 Establishing structure of the Farming System for Nutrition (FSN) approach

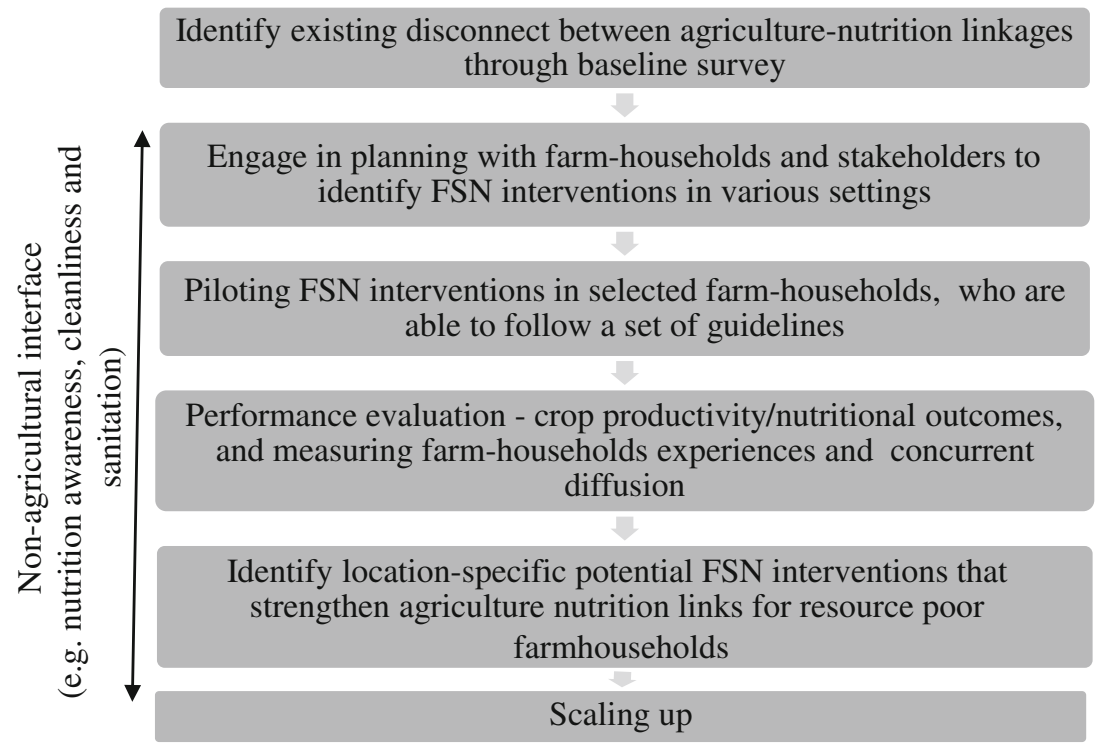


simultaneously mediating with existing government programmes related to the non-agricultural interface (e.g. Swachh Bharat Abhiyan, a campaign of the Government of India to improve communal cleanliness and sanitation and eliminate open defecation) will provide overall greater proof of impact. Specific approaches under commercial versus subsistence farming setups prevalent in Wardha and Koraput, will also provide interesting and meaningful lessons.

This study is one of the first to assess the feasibility of agriculture-nutrition linkages in districts in India with a high prevalence of severe under-nutrition. Although, we were fortunate to build on the core resources of MSSRF already operating in both Wardha and Koraput, substantial time will be required in establishing the process, demonstrating FSN interventions, performance evaluation, and finally scaling up for broader application of these types of initiatives. An end line survey of key FSN interventions in selected farm-households will measure experiences with respect to nutrition (health, dietary diversity) and non-nutritional dimensions (income, production diversity). The outcomes will provide and offer greater practical evidence and proof to policy makers for integrating and leveraging agriculture and nutrition to alleviate under-nutrition and poverty in rural India.

Acknowledgements This research was conducted as part of the Leveraging Agriculture for Nutrition in South Asia (LANSA) research programme consortium, funded by UK Aid from the UK Government. The views expressed do not necessarily reflect the official policies of the Government of the UK. The authors gratefully acknowledge the contribution of Mr. Akshaya Panda and Mr. Mahesh Maske, Coordinators of the FSN study, and Ms. Jasaswani Padhy and Ms. Rupal Wagh, Research Associates (Nutrition) at Koraput and Wardha respectively, who oversaw the conduct of the baseline survey and data entry at the two locations and the field teams who collected and entered the data. The authors also thank Mr. Rohit Parasar for insightful comments and suggestions. Special thanks to Dr. Prakash Shetty, CEO-LANSA for expert feedback in revising the manuscript.

\section{Compliance with ethical standards}

Conflict of interest The authors declare that they have no conflict of interest.

The study was approved by the Ethics Committee of the MSSRF Board of Trustees. In addition, informed consent was obtained from district level officers in Wardha and Koraput. Ethical clearance oral consent was obtained from the head of household before collecting household information and from all subjects selected for anthropometric and biochemical measurements.

Open Access This article is distributed under the terms of the Creative Commons Attribution 4.0 International License (http:// creativecommons.org/licenses/by/4.0/), which permits unrestricted use, distribution, and reproduction in any medium, provided you give appropriate credit to the original author(s) and the source, provide a link to the Creative Commons license, and indicate if changes were made.

\section{References}

Akalu, G., Taffesse, S., Gunaratna, N. S., \& De Groote, H. (2010). The effectiveness of quality protein maize in improving the nutritional status of young children in the Ethiopian highlands. Food and Nutrition Bulletin, 31(3), 418-430.

Altieri, M. A., Nicholls, C. I., Henao, A., \& Lana, M. A. (2015). Agroecology and the design of climate-resilient farming systems. Agronomy for Sustainable Development, 35, 869-890.

Anil Kumar, N., Arivudai Nambi, V., Geetha Rani, M., Israel Oliver King, E. D., Susanta, S. C., \& Mishra, S. (2015). Community agro biodiversity conservation continuum: an integrated approach to achieve food and nutrition security. Current Science, 109(3), 474487.

Baker, R. D., \& Greer, F. R. (2010). Diagnosis and prevention of iron deficiency and iron-deficiency anaemia in infants and young children (0-3 years of age). Pediatrics, 126(5), 1040-1050.

Bergamini, N., Padulosi, S., Bala Ravi, S., \& Yenagi, N. (2013). Minor millets in India: a neglected crop goes mainstream. Case study 8. In J. Fanzo, D. Hunter, T. Borelli, \& F. Mattei (Eds.), Diversifying food and diets: using agricultural biodiversity to improve nutrition and Health. Rome, Italy: Routledge: Earthscan. Bioversity International.

Birthal, S. P., Md, T. K., Negi, D. S., \& Agarwal, S. (2014). Impact of climate change on yields of major food crops in India: implications for food security. Agricultural Economics Research Review, 27(2), $145-155$.

Borrill, P., Connorton, J. M., Balk, J., Miller, A. J., Sanders, D., \& Uauy, C. (2014). Biofortification of wheat grain with iron and zinc: integrating novel genomic resources and knowledge from model crops. Frontiers in Plant Science, 5, 53.

Bruce, N., Rehfuess, E., Mehta, S., Hutton, G., \& Smith, K. (2006). Indoor air pollution. Chapter 42. In D.T. Jamison, J.G. Breman, A.R. Measham, G. Alleyne, M. Claeson, D.B. Evans, P. Jha, A. Mills \& P. Mushrove (Eds.), Disease Control Priorities in Developing Countries. 2nd edition. Washington, DC, USA: World Bank.

Caulfield, L.E., Richard, S.A., Rivera, J.A., Musgrove, P., \& Black, R.E. (2006). Stunting, wasting and micronutrient deficiency disorders. Chapter 28. In D.T. Jamison, J.G. Breman, A.R.Measham, G. Alleyne, M. Claeson, D.B. Evans, P. Jha, A. Mills \& P. Mushrove (Eds.), Disease Control Priorities in Developing Countries. 2nd edition. Washington, DC USA: World Bank.

Chandramouli, C. (2011). Census of India 2011: rural urban distribution of population. Ministry of Home Affairs, New Delhi, India. Retrieved: http://censusindia.gov.in/2011-prov-results/paper2/data files/india/Rural_Urban_2011.pdf.

Chavaz, M., \& Huenemann, R. (1984). Measuring impact by assessing dietary intake and food consumption. In D. Sahn, R. Lockwood, \& N. Scrimshaw (Eds.), Methods for the evaluation of the impact of food and nutrition programmes. Report of a workshop on the Evaluation of Food and Nutrition, UNU.

Coates, J., Rogers, B.L., Webb, P., Maxwell, D., Houser, R., \& McDonald, C. (2007). Diet Diversity Study. World Food Programme. Emergency Needs Assessment Service (ODAN), Rome, Italy.

Cole, D. C., Levin, C., Loechl, C., Thiele, G., Grant, F., Girard, A. W., Sindi, K., \& Low, J. (2016). Planning an integrated agriculture and health program and designing its evaluation: experience from Western Kenya. Evaluation and Program Planning, 56, 11-22.

Das, P. K., Bhavani, R. V., \& Swaminathan, M. S. (2014). A farming system model to leverage agriculture for nutritional outcomes. Agricultural Research, 3(3), 193-203.

del Ninno, C., Dorosh, P.A., Smith, L.C., \& Roy, D.K. (2001). The 1998 Floods in Bangladesh: Disaster Impacts, Household Coping 
Strategies, and Responses. Research Report-122, Washington, DC, USA.

Donaldson, S. I. (2015). Examining the backbone of contemporary evaluation practice: credible and actionable evidence. Chapter 1. In S. I. Donaldson, C. A. Christie, \& M. M. Mark (Eds.), Credible and actionable evidence: the foundations for rigorous and influential evaluations. Los Angeles: Sage.

FAO (2011). Guidelines for measuring household and individual dietary diversity. Food and Agriculture Organization of the United Nations, Rome. Retrieved: http:/www.fao.org/fileadmin/user_upload/wa workshop/docs/FAO-guidelines-dietary-diversity2011.pdf.

FAO (2013). Synthesis of Guiding Principles on Agriculture Programming for Nutrition. Final Draft. Food and Agriculture Organization of the United Nations, Rome. Retrieved: http://www. fao.org/fileadmin/user_upload/wa_workshop/docs/Synthesis_of Ag-Nutr_Guidance_FAO_IssuePaper_Draft.pdf.

FAO, IFAD \& WFP (2014). The State of Food Insecurity in the World: strengthening the enabling environment for food security and nutrition. Food and Agriculture Organization of the United Nations, Rome. Retrieved: http://www.fao.org/3/a-i4030e.pdf.

Frongillo, E. A., de Onis, M., \& Hanson, K. M. P. (1997). Socioeconomic and demographic factors are associated with worldwide patterns of stunting and wasting of children. Journal of Nutrition, 127, 2302-2309.

Galhena, D. H., Freed, R., \& Maredia, K. M. (2013). Home gardens: a promising approach to enhance household food security and wellbeing. Agriculture and Food Security, 2(8). https://doi.org/10. 1186/2048-7010-2-8

Gali, B., \& Parthasarathy Rao, P. (2012). Regional analysis of household consumption of sorghum in major sorghum-producing and sorghum-consuming states in India. Food Security, 4, 209-214.

Garcia-Casal, M. N., Macfarlane, B. J., Layrisse, M., Solano, L., Baron, M. A., Arguello, F., Llovera, D., Ramirez, J., Leets, I., \& Tropper, E. (1998). Vitamin A and B-Carotene can improve nonheme iron absorption from rice, wheat and corn by humans. Journal of Nutrition, $128,646-650$.

Gavali, A. V., Deokate, T. B., Choudhari, R. B., \& Kamble, B. H. (2011). Yield gap analysis of jowar in Maharashtra. Agricultural Economics Research Review, 24, 339-343.

Gillespie, S., \& van den Bold, M. (2017). Agriculture, Food Systems and Nutrition: Meeting the Challenge, Global Challenges 1, 1600002. Retrieved: http://onlinelibrary.wiley.com/doi/10.1002/gch2. 201600002/epdf.

Global Panel (2015). Improved metrics and data are needed for effective food system policies in the post-2015 era. Technical Brief No. 2. Global Panel on Agriculture and Food Systems for Nutrition, London, UK. Retrieved: https://www.glopan.org/sites/default/files/ pictures/Metrics_Brief.pdf.

GoI. (2015a). Annual report 2014-15. Department of Agriculture and Cooperation. Government of India, New Delhi: Ministry of Agriculture \& Farmers Welfare Retrieved: http://agricoop.nic.in/ Admin_Agricoop/Uploaded_File/AR\%20English\%20DoAC201415.pdf.

GoI. (2015b). Millennium development goals (MDG) India country report - 2015. Social Statistics Division, Ministry of Statistics and Programme Implementation, Government of India, New Delhi. Retrieved: http://mospi.nic.in/Mospi_New/upload/mdg_26feb15. pdf.

GoI. (2017). National Family Health Survey-4 (2015-16) India fact sheet. Ministry of Health and Family Welfare. New Delhi: Government of India Retrieved: http://rchiips.org/NFHS/pdf/ NFHS4/India.pdf.

Gonzalez, C.R. (2015). Opportunities to improve farming systems to achieve adaptability to climate change: farmers' perceptions on climate change and diversification of cropping systems as an adaptive strategy in southern Skåne, Alnarp. Retrieved: http://stud.epsilon. slu.se/8716/1/Rodriguez_C_151229.pdf.

Gragnolati, M., Shekar, M., Dasgupta, M., Bredenkamp, C., \& Lee, Y.K. (2005). India's undernourished children: A call for reform and action, The World Bank. Retrieved: http://siteresources.worldbank. org/SOUTHASIAEXT/Resources/223546-1147272668285/ IndiaUndernourishedChildrenFinal.pdf.

Grillenberger, M., Neumann, C. G., Murphy, S. P., Bwibo, N. O., Weiss, R. E., Hautvast, J. G. A. J., \& West, C. E. (2006). Intake of micronutrients high in animal source foods is associated with better growth in rural Kenyan school children. British Journal of Nutrition, 95, 379-390.

Gunaratna, N. S., De Groote, H., Nestel, P., Pixley, K. V., \& McCabe, G. P. (2010). A meta-analysis of community-level studies on quality protein maize. Food Policy, 35, 202-210.

Haghshenass, M. M., Reinhold, J. G., \& Mohammadi, N. (1972). Iron deficiency anaemia in an Iranian population associated with high intakes of iron. The American Journal of Clinical Nutrition, 25(11), 1143-1146.

Huang, T., Farmer, A.P., Goddard, E., Willows, N. \& Subhan, F. (2017). An ethnographic exploration of perceptions of changes in dietary variety in the Kolli Hills, India. Food Security, 9(4), 759-771. https://doi.org/10.1007/s12571-017-0701-3 .

ICMR. (2012). Nutritive value of Indian foods, National Institute of Nutrition. Hyderabad: Indian Council of Medical Research.

IFPRI. (2016). From promise to impact: Ending malnutrition by 2030. Washington DC: Global Nutrition Report. International Food Policy Research Institute Retrieved: http://ebrary.ifpri.org/utils/getfile/ collection/p15738coll2/id/130354/filename/130565.pdf.

Jolley, G. (2014). Evaluating complex community-based health promotion: Addressing the challenges. Evaluation and Program Planning, $45,71-81$.

Kadiyala, S., Harris, J., Headey, D., Yosef, S., \& Gillespie, S. (2014). Agriculture and nutrition in India: Mapping evidence to pathways. Annals of the New York Academy of Sciences, 1331, 43-56.

Kadiyala, S., Morgan, E. H., Cyriac, S., Margolies, A., \& Roopnaraine, T. (2016). Adapting agriculture platforms for nutrition: A case study of a participatory, video-based agricultural extension platform in India. PloS One, 11(10), e0164002. https://doi.org/10.1371/journal.pone. 0164002.

Kulkarni, A., Gadgil, S., \& Patwardhan, S. (2016). Monsoon variability, the 2015 Marathwada drought and rainfed agriculture. Current Science, 111(7), 1182-1193.

Leipziger, D., Fay, M., Wodon, Q., \& Yepes, T. (2003). Achieving the millennium development goals: The role of infrastructure. World Bank: Policy Research Working Paper, Washington DC, USA.

Masset, E., Haddad, L., Cornelius, A., \& Isaza-Castro, J. (2011). A systematic review of agricultural interventions that aim to improve nutritional status of children. London: EPPI-Centre, Social Science Research Unit, Institute of Education, University of London.

Nagarajan, S., Bhavani, R. V., \& Swaminathan, M. S. (2014). Operationalizing the concept of farming system for nutrition through the promotion of nutrition-sensitive agriculture. Current Science, 107(6), 959-964.

Nayak, D. K. (2016). Changing cropping pattern, agricultural diversification and productivity in Odisha: A district-wise study. Agricultural Economics Research Review, 29(1), 93-104.

O’ Donnell, O., van Doorslaer, E., Wagstaff, A., \& Lindelow, M. (2008). Multivariant analysis of health survey data in Analyzing health equity using household survey data: a guide to techniques and their implementation. The World Bank, Washington DC.

Oshaug, A. (1997). Evaluation of nutrition education programmes: Implication for programme planners and evaluators. Nutrition education of the public. Food and Nutrition Paper 62, 151- 
178, food and agriculture Organization of the United Nations, Rome, Italy.

Prasanna, V. (2014). Impact of monsoon rainfall on the total foodgrain yield over India. Journal of Earth System Science, 123(5), 11291145.

Rosado, J. L., Hambidge, K. M., Miller, L. V., Garcia, O. P., Westcott, J., Gonzalez, K., Conde, J., Hotz, C., Pfeiffer, W., Ortiz-Monasterio, I., $\&$ Krebs, N. F. (2009). The quantity of zinc absorbed from wheat in adult women is enhanced by biofortification. Journal of Nutrition, $139,1920 \mathrm{e} 1925$.

Ruel, M.T. (2002). Is dietary diversity an indicator of food security or dietary quality? A review of measurement issues and research needs. FCND discussion paper no.140, international food policy research institute (IFPRI), Washington DC, USA.

Sandiford, P., Cassel, J., Sanchez, G., \& Coldham, C. (1997). Does intelligence account for the link between maternal literacy and child survival? Social Science and Medicine, 45, 1231-1239.

Sathyanath, M. S., \& Rashmi, U. K. N. (2013). Prevalence and risk factors of undernutrition among under five children in a rural community. Nitte University Journal of Health Science, 3(4), 22497110.

Schultz, T. P. (1988). Education investments and returns. In H. Chenery \& T. N. Srinivasan (Eds.), Handbook of development economics (Vol. 1). Amsterdam, The Netherlands: North Holland.

Sen, J., \& Mondal, N. (2012). Socio-economic and demographic factors affecting the composite index of anthropometric failure (CIAF). Annals of Human Biology, 39, 129-136.

Shetty, P. (2009). Incorporating nutritional considerations when addressing food insecurity. Food Security, 1, 431-440.

Singh, R., \& Velu, G. (2017). Zinc-Biofortified Wheat: harnessing genetic diversity for improved nutritional quality. Science Brief: Biofortification No. 1 (May 2017). CIMMYT, HarvestPlus, and the global crop diversity trust. Bonn, Germany.

Snapp, S. S., Blackie, M. J., Gilbert, R. A., Bezner-Kerr, R., \& KanyamaPhiri, G. Y. (2010). Biodiversity can support a greener revolution in Africa. Proceedings of the National Academy of Sciences, 107, 20840-20845.

Sontakke, D. (2015). Gender and social exclusion: A study of farmers widows of Vidarbha. Vol 23, 133-146. In E. Rodriguez \& B. Wejnert (Eds.), Enabling gender equality: Future generations of the global world, Research in Political Sociology, Emerald Group Publishing Limited.

Spears, D. (2013). The nutritional value of toilets: How much international variation in child height can sanitation explain? Policy research working paper. Retrieved: doi:https://doi.org/10.1596/1813-9450-6351.

State Agriculture Policy (2013). Agriculture Department, Odisha. Retrieved: http://www.spandan-india.org/cms/data/Article/ A201671116141_20.pdf.

Talule, D. C. (2015). Post reforms cropping dimensions of the agriculture of the state of Maharashtra in India (1990-91 to 2010-11). Universal Journal of Agricultural Research, 3(2), 31-45.

Udmale, P. D., Ichikawa, Y., Manandha, S., Ishidaira, H., Kiem, A. S., Shaowei, N., \& Panda, S. N. (2015). How did the 2012 drought affect rural livelihoods in vulnerable areas? Empirical evidence from India. International Journal of Disaster Risk Reduction, 13, 454-469.

UNICEF, \& WHO (2015). Progress on sanitation and drinking water: Update and MDG assessment. The United Nations Children's Emergency Fund and World Health Organization. Retrieved: http://www.wssinfo.org/fileadmin/user_upload/resources/JMPUpdate-report-2015_English.pdf.

Valipour, M. (2015). Future of agricultural water management in Africa. Archives of Agronomy and Soil Science, 61(7), 907-927.

Valipour, M., \& Singh, V. P. (2016). Global experiences on wastewater irrigation: Challenges and prospects. Chapter 18. In B. Maheshwari, V. P. Singh, \& B. Thoradeniya (Eds.), Balanced urban development:
Options and strategies for liveable cities. AG: Springer, Switzerland.

Varian, H. (1992). Microeconomic analysis. New York: W.W. Norton \& Company.

Waized, B., Ndyetabula, D., Temu, A., Robinson, E., \& Henson, S. (2015). Promoting biofortified crops for nutrition: Lessons from orange-fleshed sweet potato (OFSP) in Tanzania. Reducing hunger and undernutrition, evidence report no. 127, Institute of Development Studies.

Wani, S.P., Chander, G., Bhattacharyya, T., \& Patil, M. (2016). Soil health mapping and direct benefit transfer of fertilizer subsidy. Research report IDC-6. International Crops Research Institute for the SemiArid Tropics. Retrieved: http://idc.icrisat.org/wp-content/uploads/ 2016/10/IDC-Report-6-Final-1.pdf.

Webb, P., \& Block, S. (2012). Support for agriculture during economic transformation: Impacts on poverty and undernutrition. Special feature on agriculture. Development and Nutrition Security. Proceedings of the National Academies of Science, 109(31), 12309-12314.

WHO. (2006). New child growth standards. Geneva: World Health Organization Retrieved: http://www.who.int/childgrowth.

WHO. (2009). Global prevalence of vitamin A deficiency in populations at risk 1995-2005: WHO global database on vitamin A deficiency. Geneva: World Health Organization.

WHO \& FAO. (2003). Diet, nutrition and the prevention of chronic diseases, Report of a joint. WHO/FAO expert consultation, WHO technical report series no. 916. Geneva: World Health Organization.

Woo, R., Daniels-Kush, R., \& Horton, E. S. (1985). Regulation of energy balance. Annual Review of Nutrition, 5, 411-433.

World Bank. (2007). From agriculture to nutrition: Pathways, synergies and outcomes. Washington DC: Agriculture and Rural Development Department Retrieved: http://siteresources.worldbank.org/INTARD/ 8258261111134598204/21608903/January2008Final.pdf.

Yannopoulos, S. I., Lyberatos, G., Theodossiou, N., Li, W., Valipour, M., Tamburrino, A., \& Angelakis, A. N. (2015). Evolution of water lifting devices (pumps) over the centuries worldwide. Water, 7 , 5031-5060.

Zimmermann, M. B., \& Hurrell, R. F. (2007). Nutritional iron deficiency. The Lancet, 370, 511-520.

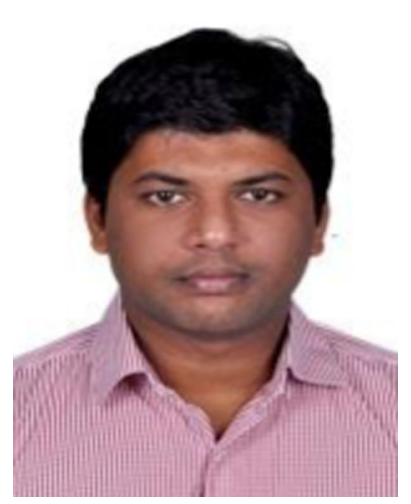

Vijaya Bhaskar A V worked as an Agronomist on the Leveraging Agriculture for Nutrition in South Asia (LANSA) research programme at the M.S. Swaminathan Research Foundation (MSSRF) for a brief period in 2016. He holds a $\mathrm{PhD}$ in Agricultural Systems funded by the John Oldacre Foundation from Coventry University, UK and an MBA from the Royal Agricultural University, UK. Vijay is currently a Postdoctoral Researcher in the Department of Ecological Plant Protection, University of Kassel, Witzenhausen, Germany. His research focuses on root traits and phenotyping for evolutionary wheat breeding materials in organic and conventional systems to identify specific adaptation traits that would be of breeding interest. In addition, Vijay works on evaluating the performance of genetically diverse wheat populations at different levels of integration of conservation agricultural technologies, as one way to address food security issues in a changing climate. 


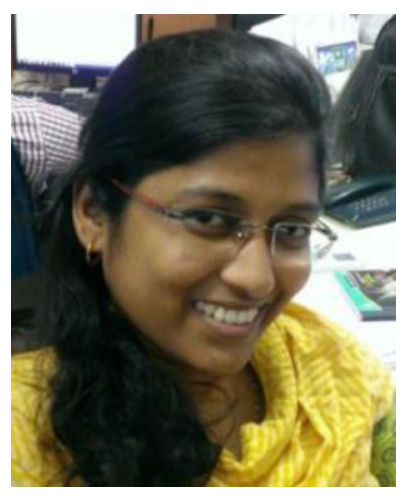

Nithya $\mathbf{D} \mathbf{J}$ is working as a Nutrition Scientist in LANSA at MSSRF, Chennai, India. She holds a doctorate degree in Food Science and Nutrition from Tamil Nadu Agricultural University. She has experience working in various projects on food processing technology and has conducted training on food processing and value addition for farmers, women's self help groups and entrepreneurs. In her current role, she is responsible for overseeing the conduct of nutrition status assessment surveys in villages under the Farming System for Nutrition study, including the analysis and interpretation of data and coordination of the nutrition awareness component of the study.

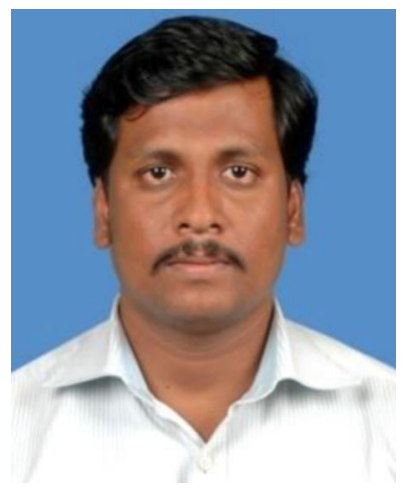

Raju $\mathbf{S}$ is working as a Senior Research Fellow under LANSA at MSSRF. He holds a Masters i n E conomics from Bharadhidasan University, Trichy, Tamil Nadu, India, and has six years of experience working in various projects with the Madras School of Economics, Chennai. Raju has expertise in sampling design, framing survey tools, questionnaire templates, pilot testing, conducting and coordinating household and market surveys and focus group discussions, data management, analysis and reporting. He is also experienced in statistical analysis using packages like STATA and SPSS. In addition to his responsibility of overseeing the collection and managing survey data, he is engaged in studying the feasibility and challenges of introducing millets in the Public Distribution System in India.

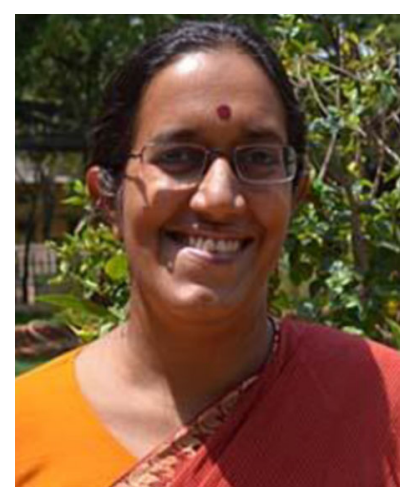

Bhavani R V has been working on food and livelihood security issues at MSSRF for more than fifteen years. Holding a $\mathrm{PhD}$ in Economics from the University of Madras and an erstwhile banker, she is currently Programme Manager, LANSA, responsible for coordinating with partners in the consortium research programme as well as oversight of research under LANSA at MSSRF. 